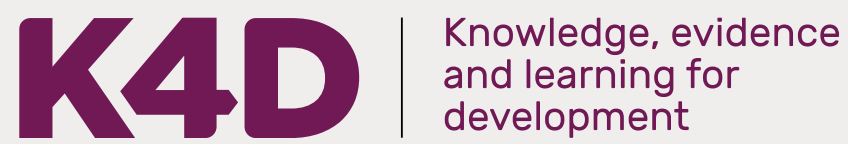

\section{Education, Conflict, and Stability in South Sudan}

Huma Haider Independent Consultant July 2021 


\section{About this report}

The K4D Emerging Issues report series highlights research and emerging evidence to policymakers to help inform policies that are more resilient to the future. K4D staff researchers work with thematic experts and the FCDO to identify where new or emerging research can inform and influence policy.

This report is based on 10 days of desk-based research.

K4D services are provided by a consortium of leading organisations working in international development, led by the Institute of Development Studies (IDS), with the Education Development Trust, Itad, University of Leeds Nuffield Centre for International Health and Development, Liverpool School of Tropical Medicine (LSTM), University of Birmingham International Development Department (IDD), and the University of Manchester Humanitarian and Conflict Response Institute (HCRI).

For any enquiries, please contact helpdesk@k4d.info.

\section{Acknowledgements}

We would like to thank Naomi Pendle, who served as an external expert reviewer, provided guidance, and contributed to the writing of this report.

We would also like to thank Barbara Cheney, who copy-edited this report.

\section{Suggested citation}

Haider, H. (2021). Education, Conflict and Stability in South Sudan. K4D Emerging Issues Report 46. Brighton, UK: Institute of Development Studies. DOI: 10.19088/K4D.2021.129

\section{Copyright}

This report was prepared for the UK Government's Foreign, Commonwealth \& Development Office (FCDO) and its partners in support of pro-poor programmes. It is licensed for non-commercial purposes under the terms of the Open Government Licence v3.0. K4D cannot be held responsible for errors or any consequences arising from the use of information contained in this report. Any views and opinions expressed do not necessarily reflect those of FCDO, K4D, or any other contributing organisation.

(C) FCDO - Crown copyright 2021.

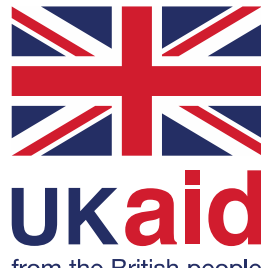




\section{Contents}

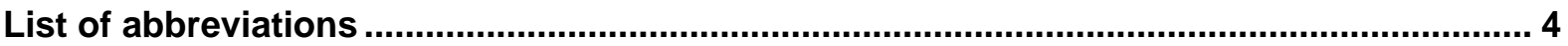

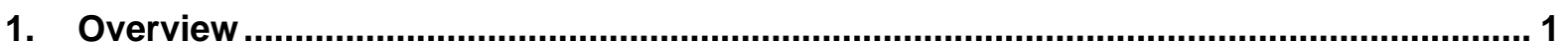

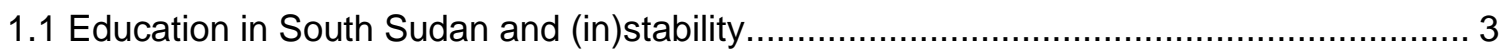

1.2 Donor involvement in education in South Sudan ........................................................... 5

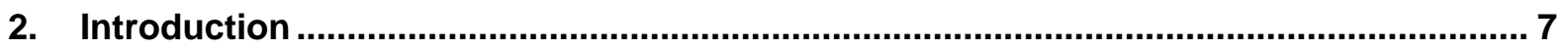

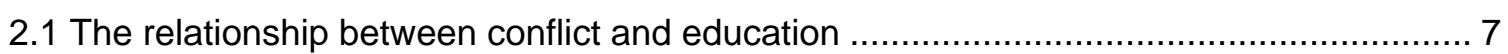

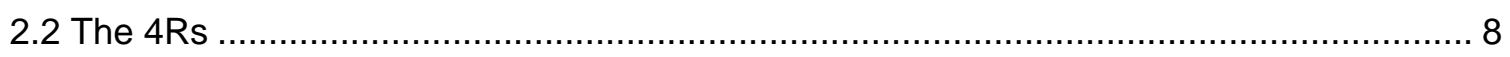

2.3 Conflict dynamics in South Sudan ......................................................................... 9

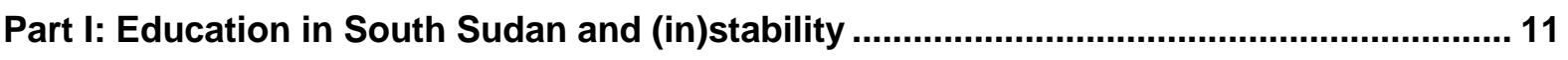

3. Politicisation of education, impact of conflict, and budget shortfalls........................... 11

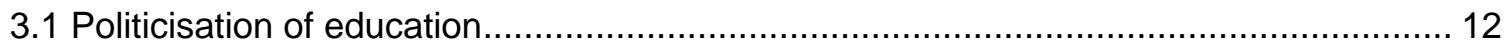

3.2 Effects of conflict and inadequate investment in education ....................................... 13

4. (In)equity, exclusion/inclusion, and marginalisation in the education sector .............. 16

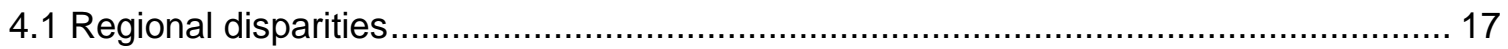

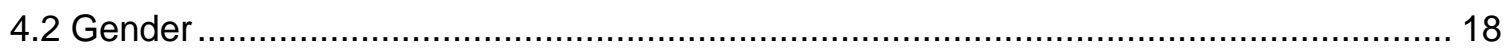

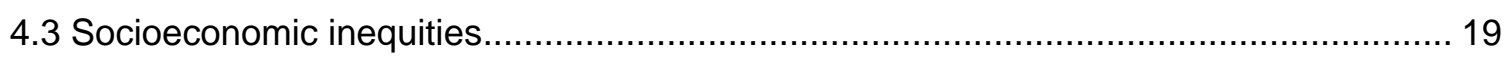

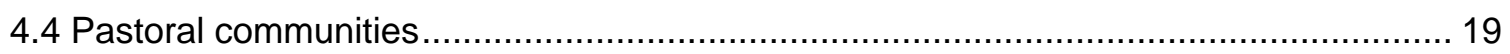

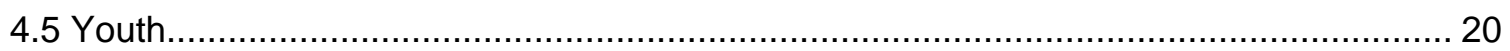

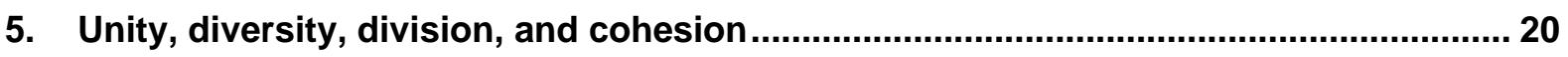

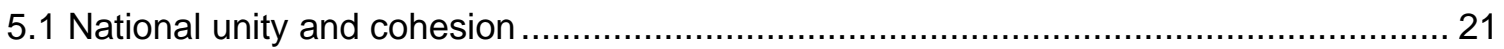

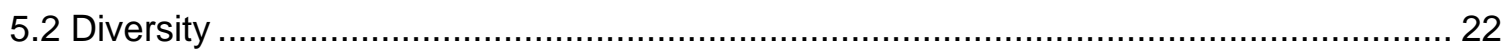

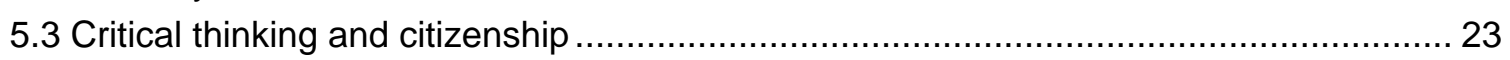

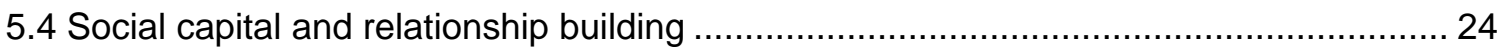

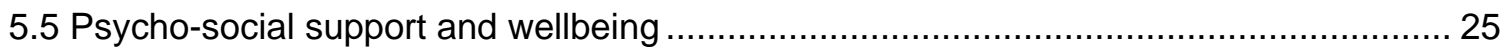

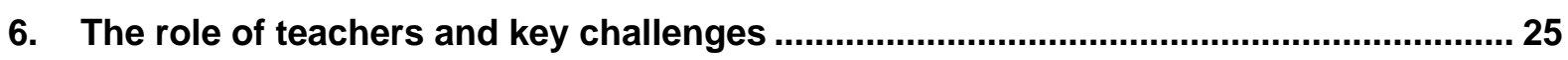

Part II: Donor Involvement in Education in South Sudan ................................................ 27

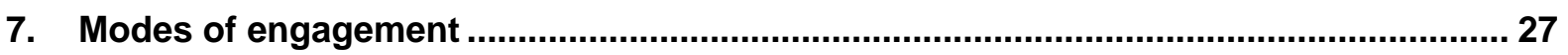

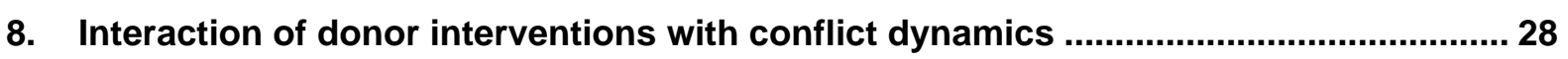

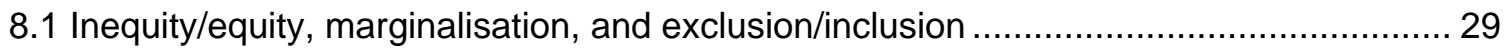

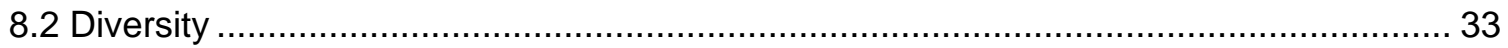

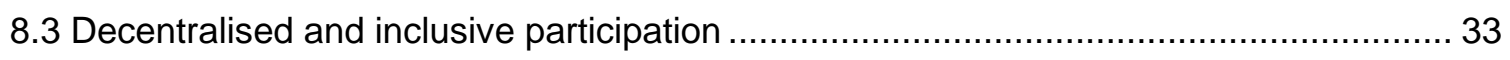

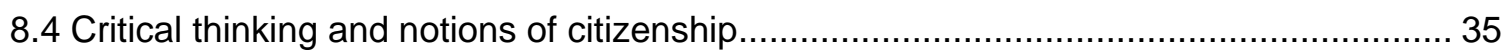

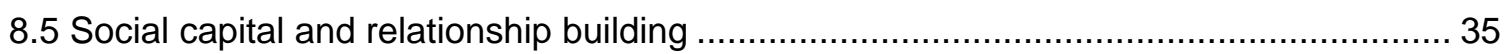

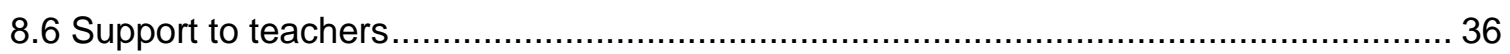

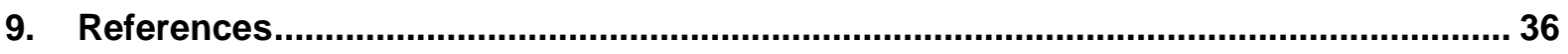




\section{List of abbreviations}

\begin{tabular}{|c|c|}
\hline ALP & Accelerated Learning Programme [Oxfam] \\
\hline CPA & Comprehensive Peace Agreement [2005] \\
\hline FCDO & Foreign, Commonwealth \& Development Office \\
\hline 4Rs & Redistribution, Recognition, Representation, and Reconciliation [framework] \\
\hline GESS & Girls' Education South Sudan \\
\hline GRSS & Government of the Republic of South Sudan \\
\hline IDP & internally displaced person \\
\hline KER & knowledge, evidence, and research \\
\hline MoEST & Ministry of Education, Science and Technology \\
\hline MoGEI & Ministry of General Education and Instruction \\
\hline MT & mother-tongue [language] \\
\hline NGO & non-governmental organisation \\
\hline NRC & Norwegian Refugee Council \\
\hline PoC & Protection of Civilian \\
\hline PTA & parent-teacher association \\
\hline R-ARCSS & $\begin{array}{l}\text { Revitalised Agreement on the Resolution of the Conflict in the Republic of South } \\
\text { Sudan }\end{array}$ \\
\hline SAMS & Schools Attendance Monitoring System \\
\hline SBM & school-based management \\
\hline SDP & school development plan \\
\hline SMC & school management committee \\
\hline SPLA & Sudan People's Liberation Army \\
\hline SPLM & Sudan People's Liberation Movement \\
\hline SSSAMS & South Sudan Schools Attendance Monitoring System \\
\hline SSTEP & South Sudan Teacher Education Project \\
\hline TPD & teacher professional development \\
\hline
\end{tabular}




\section{Overview}

Violent conflict has been the primary mode of political contention in South Sudan since 1955 (de Waal et al., 2017). South Sudanese-led armed opposition groups fought two civil wars against the government of Sudan (1955-1972 and 1983-2005) and multiple, concurrent inter- and intracommunal conflicts (O'Grady, 2017). The 2005 Comprehensive Peace Agreement (CPA) that ended Sudan's second civil war was negotiated between the Sudan People's Liberation Movement (SPLM), the leading southern movement and armed group, and Sudan's ruling National Congress Party. It excluded other political and military opposition groups in the north and south. These political divisions, as well as wartime social fragmentation, remained unaddressed after the CPA was signed (ibid.). South Sudan became the world's newest nation on 9 July 2011. Political tensions between the SPLM ruling party and the opposition parties, each with links to military groups, became the fault lines in the emerging nation-state (ibid.; Johnson, 2014). Armed conflicts in South Sudan escalated in 2012 and 2013, and large-scale war broke out in Juba and other state capitals in December 2013.

The ongoing conflict has raised concerns about the nature of the governing elites of the state (de Waal et al., 2017). Politicians have often used exclusionary ethnic identities and identity boundaries to provoke fear, mobilise support, and gain legitimacy in the absence of providing more tangible public resources and service delivery (McCrone \& the Bridge Network, 2021; de Waal et al., 2017). Dissatisfaction among the South Sudanese citizenry with public service delivery, including education, has been growing and is likely to increase if provision does not improve (McCrone \& the Bridge Network, 2021; Novelli et al., 2016).

Despite the many challenges, the transitional period (2005-2011) after the conclusion of the CPA witnessed significant improvement in access to education (Mayai, 2021). Governments, donors, elites, and the diaspora invested in schools and educational programmes in South Sudan (Pendle, 2021). The educational system has deteriorated, however, since independence and to a much greater degree after the eruption of violence in 2013, in terms of infrastructure, staffing of teachers, access, and governance of schools (Ibreck et al., 2021; Mayai, 2021; Buchanan et al., 2019). Many schools suffered from attacks or were used as army barracks during armed conflict, and teachers were killed or fled into exile (lbreck et al., 2021). At the same time, other indicators suggest a growth in school enrolment. Between 2014 and 2018, the number of pupils registered in the Foreign, Commonwealth \& Development Office (FCDO)-funded Schools' Attendance Monitoring System rose from 928,000 in 2014 to over 1.7 million in 2018 (GESS, 2018a, p. 1).

This Emerging Issues Report explores the relationship between education, conflict, and (in)stability in South Sudan, drawing on a wide range of academic, policy, and programming literature. There is a growing body of research on the ways in which education can both exacerbate conflict and contribute to peace. The 4Rs framework (focusing on aspects of Redistribution, Recognition, Representation, and Reconciliation) provides a holistic way to explore and address the education system's relationship to economic, social, cultural and political development processes; and its role in producing or exacerbating inequalities that fuel grievances and ultimately conflict (Novelli et al., 2019, 2016). The 4Rs framework is adopted throughout this report, at the start of each main section, providing summaries of key issues in the delivery of education and outcomes in South Sudan. These summaries are also presented in this overview. The report also looks at the interaction of donor interventions in education with conflict and stability in South Sudan, focusing on the Girls' Education South Sudan (GESS) programme (see below), but also drawing on a few other interventions. While there is a range of donor 
reports and other literature that outline and discuss these initiatives and their impacts, there is limited research that makes explicit connections to their interactions with conflict and (in)stability.

\section{Overview of the projects discussed in this report}

Below are some selected examples of interventions. These include examples that operate on a national scale and those that have a local focus.

GESS: The Girls' Education South Sudan (GESS) programme was designed in 2013. Led by the FCDO in partnership with the Canadian Government, it is now in its second phase (GESS 2). The programme works with the Government of South Sudan nationwide to reduce barriers to education and improve attainment levels for children, particularly girls. To-date the programme has supported 1 :

- The provision of Cash Transfers to 685,598 individual girls, providing more financial support to more girls than ever before to mitigate potential risks to their safety and development during year-long COVID-19 related school closures and giving them the best possible chance of reenrolment;

-Activities to change community attitudes towards education, focused on participation in distance learning during school closures, messaging around COVID-19 safe reenrolment and educational radio programmes targeted at over two million children;

-Government policymaking on inclusive education, safeguarding and safe school reopening;

-Quality education activities including mentoring and enrolment of students and teachers in Learning Groups and skills training;

-Innovative research to improve evidence on what works and running of the Schools' Attendance Monitoring System (SAMS), which reports on teacher and pupil attendance.

SSTEP: The South Sudan Teacher Education Project (SSTEP), starting in 2011 and funded by USAID, implements in-service training programmes for teachers and provides certification.

Training is focused on curriculum development, using the revised Unified Curriculum training system, with a specific focus on improving teachers' skills in teaching literacy and numeracy. USAID terminated the project in 2014, prior to completion, due to ongoing violence in South Sudan, beginning in the fall of 2013. SSTEP worked at the central level and with all 10 states (Vinogradova, 2014).

Room to Learn: This USAID funded project (2013-2016) sought to encourage and enable community participation in improving education access, quality and safety. Project staff engaged parents and teachers as well as women, youth, and other community members in developing and implementing school improvement plans. These plans were informed by their participation in a 'good school' visioning exercise; their interpretation of data on measures of access, quality, and safety; and their appraising community assets that could contribute to implementing the

${ }^{1}$ See GESS Annual Review (forthcoming). Available at: https://devtracker.fcdo.gov.uk/projects/GB-GOV-1300449/documents 
school improvement plan. The project provided in-kind grants (mainly books and other instructional materials) and organised one capacity building workshop for PTA members and one for teachers, but was not able to provide other kinds of support (e.g., funds for construction, ongoing technical assistance). The project's implementation - and the daily life of school community members - were both interrupted and challenged by periods of violent conflict between political groups associated with the two major ethnic groups (Dinka and Nuer) (Ginsburg, 2017).

Oxfam accelerated learning programme (ALP): Implemented in Panyijar County in former Unity State in South Sudan, this programme (2014-2018) targeted both internally displaced persons (IDPs) and host populations - many of whom never had opportunities to access education in their county due to lack of facilities and protracted conflict. ALP focused on the age group 12-18 years old and offered eight years of primary education in four years (Nicholson, 2018).

Ibba girls' school: This girls' residential school opened in 2014 as a joint collaboration between local community leaders, the Ibba County Commissioner and a UK team. It offers places to girls regardless of background, status or parental income, with the aim of empowering young women with valuable knowledge and skills. Beginning in 2014 with 40 ten-year old girls, the school now educates 220 girls, with a target to reach 360 girls by 2022. Prior to joining the school, the parents of each girl must agree explicitly that they will support attendance, retention and progress through to the end of secondary school (Philip et al., 2018).

\subsection{Education in South Sudan and (in)stability}

\subsubsection{Politicisation of education, impact of conflict, and budget shortfalls}

Redistribution: Exclusionary practices in education can be traced to colonial policies and practices, which resulted in differential resource distribution across the region (Duany et al., 2021). Recent research finds that low investment in education is negatively associated with conflict (Kuol \& Oringa, 2021). Political elites often send their own children abroad for education or to private schools within South Sudan, leaving little incentive for public investment in the South Sudanese education system (Raza et al., 2019).

Recognition: A key driver of instability in South Sudan has been the imposition of a hegemonic culture through the education system in a very diverse country (ibid.). Depending on the ruling government, the language of instruction has alternated between Arabic and English (Vanner et al., 2019). Official policy since the CPA promotes mother-tongue (MT) education (referred to also as indigenous, local, or now 'national languages'), but teaching and learning resources in MT are scarce, and the existence of over $60 \mathrm{MT}$ languages makes the policy challenging to implement (ibid.).

\subsection{2 (In)equity, exclusion/inclusion, and marginalisation in the education sector}

Redistribution: There is wide regional disparity in education enrolment and attainment across states and counties, which correlates with the occurrence of conflict events (Novelli et al., 2016; Reisman \& Janke, 2015). There is no systematic policy, however, to redress these disparities (Novelli et al., 2016). There are greater access challenges in rural areas due to the long distance from home to school; an inadequate number of schools; and timetables that conflict with cattle- 
herding duties (Bul, 2019; Clugston, 2018; Novelli et al., 2016). Girls face greater challenges, with approximately $75 \%$ of girls unenrolled in primary school, and greater likelihood of dropping out than boys (Toma, 2019, 11; Lodou \& Oladele, 2018). When poor families struggle to cover school costs, they often prioritise boys' education over girls' due to prevailing cultural gender norms (Duany et al., 2021; Toma, 2019; Novelli et al., 2016).

Many wealthy or elite families send their children to neighbouring countries for higher quality education or to private schools, which improves their employment prospects and reproduces an elite class (Duany et al., 2021; Raza et al., 2019; Novelli et al., 2016). The creation of an unskilled generation of young South Sudanese among those excluded can produce grievances and lead to pressures for conflict, and susceptibility to mobilisation by armed forces (Diing et al., 2021; Novelli et al., 2016; Mayai \& Hammond, 2014).

Recognition: The challenges that female learners face in pursuing an education also contributes to low numbers of female teachers, who could act as role models for girls and provide an incentive for enrolment and attendance of girls in school (Buchanan et al., 2019). Only 6\% of trained teachers are female (Toma, 2019, p. 11). Curriculum and teaching materials can also play a key role in perceptions and views of girls, boys, women, and men, which can influence attitudes towards schooling (Vanner et al., 2019). Transformative educational materials deliberately depict women and girls in non-traditional gender roles and as competent and confident (ibid.). Curriculums may also need modification to achieve greater cultural and economic relevance for pastoral communities (Bul, 2019; Novelli et al., 2016).

\subsubsection{Unity, diversity, division, and cohesion}

Recognition: Prior oscillation between Arabic and English as the main language of instruction occurred at the expense of MT languages (Momo, 2021). While official educational policy now promotes teaching in these languages, teachers have generally not been trained to teach them, nor are there adequate learning materials (ibid.; Vanner et al., 2019). Educational policy and strategy that emphasise 'South Sudanese identity' can avoid potentially problematic aspects of ethnic identity; however, it may limit the space for teachers and children to teach and learn respect and appreciation of each other despite ethnic differences (Skårås et al., 2020).

Textbooks, while containing positive references to shared spaces with newcomers, stemming from displacement, lack references to the benefits of diversity and have few positive references to Islamic or African religions in contrast to Christianity (Vanner et al., 2019). New textbooks provide an opportunity for materials that address these shortfalls (ibid.). There may also be geographic and socioeconomic inequities in terms of student exposure to diverse groups, as school diversity is often greater in urban areas (Novelli et al., 2016).

Representation: Research finds that education actors at school and payam ${ }^{2}$ levels feel their voices and concerns are neglected, potentially limiting recognition of diverse experiences and identities within states, and reproducing patterns of marginalisation within national curricula (Novelli et al., 2016). At the same time, there have been efforts to enhance local-level community participation, particularly through local school governing bodies (Ginsburg et al., 2017).

\footnotetext{
${ }^{2} \mathrm{~A}$ payam is the administrative division below counties. The unit of division was introduced by the SPLM/A.
} 
Reconciliation: Research emphasises the importance of students in South Sudan learning about the geography, history, people, and traditional knowledge of their own country to strengthen connections to the past (Novelli et al., 2016). Critical thinking is a key competency in the curriculum framework, seen as necessary to examine root causes of conflict and to question divisive systems that lead to conflict (Skårås et al., 2020; Vanner et al., 2019). Cooperation is another key competency, which can be particularly important in teaching children to come together across ethnic lines (Skårås et al., 2020). Classroom visits reveal, however, that teachers do not necessarily facilitate participation, critical thinking, and cooperation in the lessons observed (ibid.). Nonetheless, one study finds that education can nurture trust among different groups by allowing for regular interaction, which can reduce fear and stereotypes of the 'other' (Kuol \& Oringa, 2021). There is also anecdotal evidence that efforts to bring teachers together from different warring groups for training activities had a positive impact on relationship building, with greater willingness to work together as professionals (Winrock International, 2017). Schools and teachers can also help to provide psycho-social support to students to address trauma resulting from violence (Heltne et al., 2020). At the same time, teachers require psycho-social support themselves in order to be able to effectively support children (ibid.).

\subsubsection{The role of teachers and key challenges}

Teachers in South Sudan remain poorly paid with limited or no training, while working in extremely challenging teaching environments (Ibreck et al., 2021; Buchanan et al., 2019). Less than half (47\%) of South Sudan's teachers have received formal teacher training (Toma, 2019, p. 11), and many teachers have not completed primary and secondary education. In addition, many teachers were educated in Arabic, with limited proficiency in English - the current main language of instruction (Winrock International, 2017). In conflict-affected contexts, teachers also require additional training in transformative education, such as how to promote critical thinking and to recognise gender biases in the curriculum and their teaching practices (Buchanan et al., 2019). Teacher absenteeism, caused in large part by lack of pay, is another key problem in South Sudan, wasting valuable financial resources and undermining learning for students (Târlea et al., 2021). Female teachers were more likely to report being regularly absent from school, with health reported as a key reason for absence (ibid., p. 7).

\subsection{Donor involvement in education in South Sudan}

\subsubsection{Modes of engagement}

Government officials, schools and teachers, private actors, international and local donors, agencies, non-governmental organisations (NGOs), community leaders, and volunteers have all contributed to the delivery of education in South Sudan (lbreck et al., 2021). The fragmentation of the education sector can in some cases be seen as a potential source of tension (Novelli et al., 2019). Divergences between government schools and private schools, for example, are generally associated with inequalities (see lbreck et al., 2021; Novelli et al., 2016).

Some international development donors channel resources directly to local authorities, such as county governments. While this can strengthen local service delivery and participation, some have argued that this can contribute to tensions between central and local governments, potentially undermining state legitimacy at the national level (Novelli et al., 2016). Yet, in a context where central government has regularly struggled to distribute funds to a more local level, directly working with local governments has ensured that funds have reached schools. 
Government services may also be associated with limited representation and recognition of diverse communities, linked to broader dynamics of exclusion (ibid.).

\subsubsection{Interaction of donor interventions with conflict dynamics}

Redistribution: The geographic distribution of international partners and education resource allocation is considered, in some cases, to have fuelled and reinforced geographic inequities and contributed to pressures for conflict (Novelli et al., 2016). Teaching training, for example, is often centred in either 'safe zones' or urban areas, leaving some of the most disadvantaged parts of South Sudan, including conflict-affected areas, with few to no teacher training options (Buchanan et al., 2019). At the same time, donors are cognisant of the potential for resource distribution to contribute to community tensions, adopting conflict-sensitive criteria (Novelli et al., 2016).

Research suggests that the GESS cash transfers have contributed to a significant increase in the proportion of girls enrolled in school (Ibreck et al., 2021; Jo, 2019; Clugston, 2018). More than half of school-age girls remain out of school, however, due in part to the inability of the cash transfers alone to adequately offset other barriers. These include physical dangers in travelling to school and the ongoing practice of early marriage for girls (Clugston, 2018). Other components of the GESS programming seek to address these issues, for example, radio programming seeks to support behaviour change by presenting different portrayals and representations of girls and of gender that are not focused on domestic duties or on marriage (Bul, 2019).

Recognition: While GESS radio programmes, aimed at awareness raising and behavioural change, have been broadcast in nine languages, this falls short of accounting for all 'national languages' (GESS, 2020a). Visual storytelling print resources have also been developed in such a way that community members, seeking to raise awareness and inform and engage the community (community mobilisers), can go through them in their own national language (GESS, 2020a). Donor programming has also incorporated gender-responsive learning materials that use male and female examples: girls see themselves represented, increasing their likelihood to engage with education (UNESCO, 2020). The representation of powerful female role models in curriculum content can increase the confidence of girls and change attitudes relating to gender roles (Buchanan et al., 2019).

School curricula also needs to be relevant to the cultural and livelihood systems of cattle-keeping and rural communities, such as through the incorporation of cultivation and animal husbandry elements (Novelli et al., 2016) or the application of numeracy - for example, to assist with participation in the cattle trade. In addition, support to schools located between counties, payams, or communities can promote school diversity and reconciliation by bringing together members of conflicting groups (ibid.).

Representation: Development partners may engage more prominently with state and county authorities, which leaves the voices and concerns of payam-level education officials and school manager and teachers possibly unaddressed (Novelli et al., 2016). This can also adversely affect the diversity of views in education policy and planning. Donors have, however, been involved in programmes aimed at creating capacity for community-level participation, particularly through school-based management (SBM) (Ibreck et al., 2021; Winrock International, 2017). Studies present mixed findings on parent-teacher associations (PTAs): some (e.g. Oxfam's Accelerated Learning Programme) have strong female representation and have been effective in engaging pastoralist communities and girls (Nicholson, 2018); whereas others (e.g. Room to Learn) were either inactive or minimally active, due in part to lack of capacity (Winrock International, 2017). In 
the case of the GESS programme, there are concerns that since the establishment of a PTA or similar governing body is a key requirement for schools to be eligible for a GESS grant, PTAs may be created solely for this purpose and exist in name only (Kang, 2017).

Reconciliation: In South Sudan, where geographic boundaries are often indicative of inter-group tensions, bringing together representatives from different states in education sector planning has facilitated awareness of commonalities (Diaz-Varela et al., 2016). In addition, research on the South Sudan Teacher Education Project (SSTEP) finds that teachers should be trained in addressing topics such as human rights, citizenship, reconciliation, conflict dynamics and transformation, identity issues, non-violent alternatives, and historical memory (Reisman \& Janke, 2015). Even if training is focused on traditional subject matter (e.g. English and mathematics), conflict-sensitive messages should be integrated into these subjects (ibid.). Research on Ibba Girls' School, which seeks to educate girls so that they can contribute to maintaining peace and advocate for human rights, finds that girls who attend the school report developing respect for other people and helping to stop quarrels (Philip et al., 2019).

\section{Introduction}

\subsection{The relationship between conflict and education}

There is a growing body of research on the ways in which education can both exacerbate conflict and contribute to peace. These are discussed in prior K4D reports: Millican (2021); Price (2019); and Haider (2014).

Education can be a driver of conflict if:

- Education policies and practice are inequitable and exclusionary: Countries with educational inequalities between identity groups are more likely to experience violent conflict (Millican, 2021). Children or youth from one group may have less access to education (and associated employment opportunities) than other groups. This can create grievances that act as a motivation to engage in conflict. Such exclusion may reflect broader patterns of inequalities such as gender, class, geographic, and/or ethnic inequalities (see Haider, 2014).

- Education systems reinforce identity grievances and promote intolerance: Identity issues can play out through the particular language of instruction, curricula that favours a dominant culture, one-sided teaching of history, and portrayal of negative stereotyping of groups in textbooks and in classroom teachings. Identity is often closely tied with dynamics of equity and exclusion (see Haider, 2014).

- Educational curricula promote militarism: The militarisation of textbooks and classroom teachings can produce military mindsets among children and youth and the belief that solutions to problems are achieved through force (see Haider, 2014)

At the same time, education can build stability and contribute to peace. Systematic global studies demonstrate a relationship between higher education levels in a country's population and lower risk of violent conflict (see Millican, 2021).

- Education can act as a peace dividend: Education provision can be one of the most visible benefits of peace, underpinning the value of peace agreements for all members of society (see Price, 2019; Haider, 2014).

- Education can help strengthen state legitimacy: State provision of education can boost trust in the state and reduce grievances that fuel violence (see Millican, 2021). Opportunities 
for participation and representation in decision making can also strengthen state-society relations and perceived state legitimacy (Novelli et al., 2016). Accountability and participation can be promoted through the involvement of local communities in planning curricula and other forms of decision making, and the incorporation of parents and children in school management councils or committees and PTAs (see Haider, 2014).

- Education can help strengthen social cohesion and relationship building: Interactions within the classroom, the participation of different groups in local-level education governance, and inclusive curricula and textbooks, can also have the effect of building relationships across identity groups and promoting diversity (see Millican, 2021; Price, 2019; Haider, 2014). Education can also contribute to social cohesion by teaching principles of unity, citizenship, civic action, and social justice (see Millican, 2021; Haider, 2014). Links between education and active citizenship can produce and strengthen a resilient social contract as a driver of peace (Kuol \& Oringa, 2021).

- Education can improve wellbeing and reduce an individual's propensity for violence: Studies have indicated that a return to school in conflict-affected contexts can provide a protective environment for children and youth, a safe space for them and educators to interact, a sense of continuity and 'normalcy', and an entry point for psycho-social support (see Millican, 2021; Heltne et al., 2020).

\subsection{The 4Rs}

The 4Rs framework provides a holistic way to explore and address the education system's relationship to economic, social, cultural, and political development processes and its role in producing or exacerbating inequalities that fuel the grievances that often drive conflicts (Novelli et al., 2019, 2016). Its central normative position is that inequalities and injustice in education are important for understanding the reasons for violent conflict and that addressing such inequalities is thus necessary to promote sustainable peace (Novelli et al., 2019).

Illustrated in Figure 1, the 4Rs comprise (ibid., p. 71):

- Redistribution: Addressing inequalities relating to the funding, distribution of resources, and management of education.

- Recognition: Addressing inequalities and injustices related to cultural representation and misrecognition and respecting difference.

- Representation: Addressing inequalities linked to participation and democratic deficits in the governance and management of education, and ensuring participation.

- Reconciliation: Dealing with the legacies of the conflict and exploring how education might bring communities together through processes of healing and psycho-social interventions and transitional justice. 


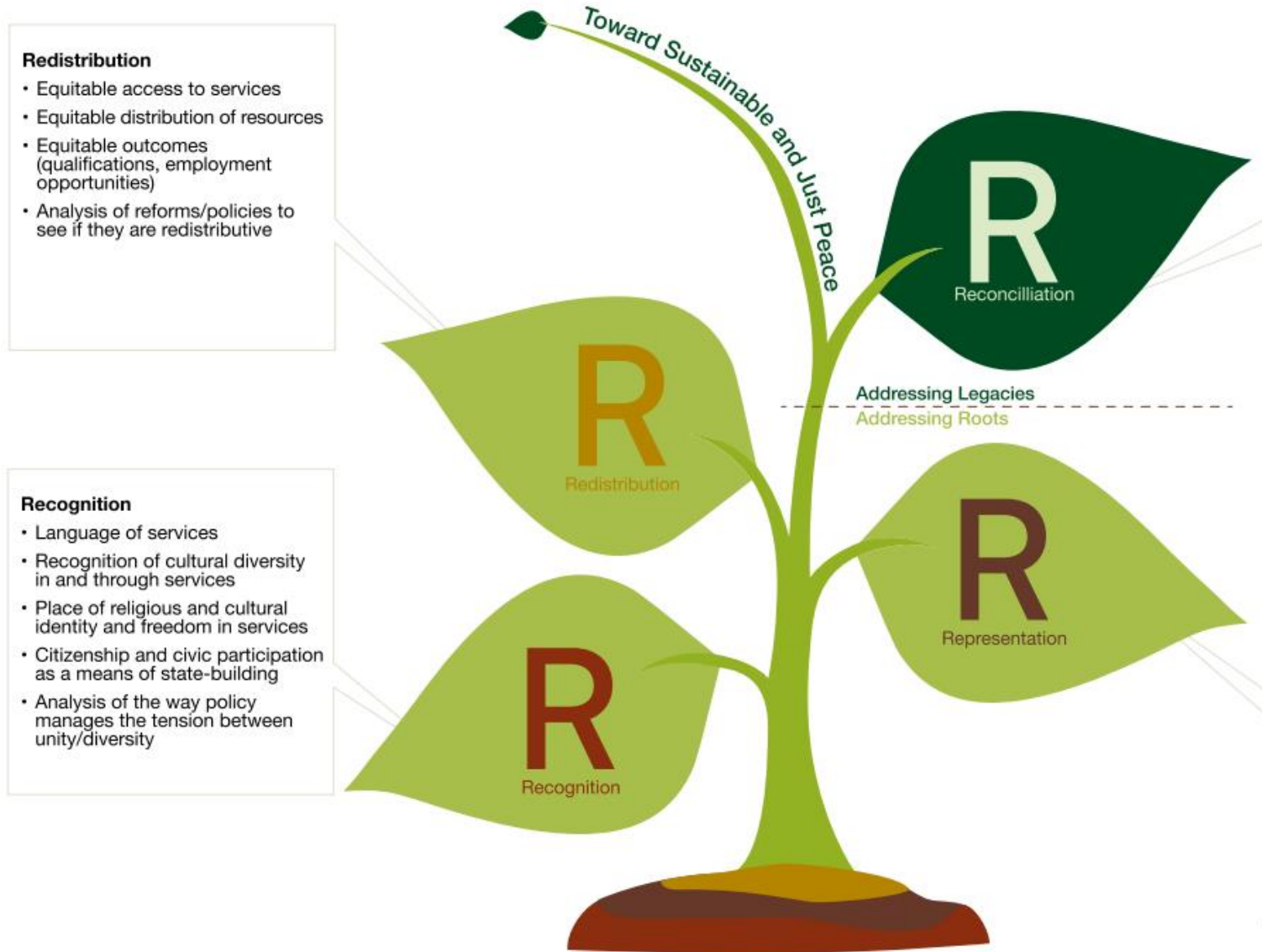

Reconciliation

- Addressing historic and contemporary economic, political, and cultural injustices

- Analysis of how services strengthen/weaken social cohesion

- Acknowledgement and public debate about the past and its relevance to the present and future

- Levels of trust-vertical (in government and services it provides at all levels) and horizontal (between groups)

Source: Novelli et al., 2019, p. 72. Reproduced with permission.

While separated for analytical purposes, the dimensions of the $\mathbf{4 R s}$ are closely interlinked and can be reinforcing or conflictive (Novelli et al., 2019). For example, recognising formerly excluded languages in education and redistributing resources to train teachers and develop curriculum materials to support this process could improve representation of minorities in decision-making positions at the school governance level or later in political positions (ibid.). This process could also hinder the reconciliation process, however, as it can be challenging to incorporate all minority languages. This can create resentment among various groups of students, based on included and excluded languages (ibid.).

\subsection{Conflict dynamics in South Sudan}

From the mid nineteenth century, South Sudan experienced a violent colonial conquest and subsequent colonial governance characterised by oil extraction, neglect, and racial oppression. This was continued after Sudan's independence by governments headquartered at Khartoum (Thomas, 2015). The people of southern Sudan violently opposed these regimes. Armed opposition groups led by southern Sudanese fought two civil wars against the government of Sudan (1955-1972 and 1983-2005) and multiple, concurrent inter- and intra-communal conflicts (O'Grady, 2017). Violent conflict has been the primary mode of political contention since 1955 (de Waal et al., 2017). 
The 2005 Comprehensive Peace Agreement (CPA) that ended Sudan's second civil war was negotiated between the Sudan People's Liberation Movement (SPLM)/Sudan People's Liberation Army (SPLA), the leading southern movement and armed group, and Sudan's ruling National Congress Party. It excluded other political and military opposition groups in the north and south. These political divisions, as well as wartime social fragmentation, remained unaddressed after the CPA had been signed (O'Grady, 2017). Communities were further isolated as the transition government was too weak to provide security and economic wellbeing (ibid.).

South Sudan became the world's newest nation on 9 July 2011, through a referendum. It served as a unifying force in southern Sudan, with the majority of the population uniting behind the objective of independence (ibid.). Subsequent to the referendum, political tensions between the SPLM ruling party and the opposition parties, each with links to military groups, became the fault lines in the emerging nation-state (ibid.; Johnson, 2014).

Armed conflicts in South Sudan escalated in 2012 and 2013, and large-scale war broke out in Juba and other state capitals in December 2013. Initially the army divided along historic lines of allegiance (Johnson, 2014), but histories and norms were remade and groups mobilised along new norms of revenge and ideas of ethnicity (Pendle, 2020). By 2018, the war had resulted in an excess death toll of 382,900 , the internal displacement of about 2 million people, and 2.5 million refugees in neighbouring countries (Checchi et al., 2018, pp. 7, 19). Displacement has prevented farming, while looting and cattle rustling have destroyed many people's assets (O'Grady, 2017). The war has greatly undermined economic development and political reform (ibid.).

Patronage and elite interests: The ongoing conflict has raised concerns about the nature of the governing elites of the state (de Waal et al., 2017). Despite being a resource-rich nation, decades of violent conflicts and tensions with (Northern) Sudan, compounded by chronic underdevelopment and economic volatility, have impacted South Sudan's ability to provide basic services to its people (O'Grady, 2017). Education policy by a succession of governments in the twentieth century had entrenched southern marginalisation and exclusion from political and government leadership (Thomas, 2015).

'Peace' following the CPA did not result in a redistribution of resources and power in favour of most of the South Sudanese population, but instead concentrated resources and influence in Juba and in a small handful of elites (McCrone \& the Bridge Network, 2021). At the same time, communities continued to exist in a state of chronic underdevelopment (ibid.). Many contemporary land conflicts centre on cattle ownership and grazing rights, which are driven by elite interests (ibid.), in addition to changes in the value of land with an increase in private ownership.

Politicisation of identity: South Sudan's colonial experience and civil wars have produced the tribalisation or sectarianisation of communities (ibid.). Politicians have often used exclusionary ethnic identities and identity boundaries to provoke fear and to mobilise support (de Waal et al., 2017). Elites have invoked these forms of divisive identity making as a way to gain legitimacy and influence, in the absence of providing more tangible public resources and service delivery (McCrone \& the Bridge Network, 2021).

Politicised boundary demarcation, resulting in changes in the number of subnational states, has also contributed to uncertainty in local governance and delivery of public goods and to new rounds of conflict (ibid.). In 2020, South Sudan reverted to 10 subnational states, in place of the 32 states controversially created in 2017 (Pritchard \& Verjee, 2021). De-linking local governance 
units and positions from particular 'ethnic fiefdoms' are a way to prevent sectarianisation of local politics (McCrone \& the Bridge Network, 2021).

Public service provision: The dissatisfaction of the citizenry with public service provision is likely to increase (ibid.). A national public opinion survey in South Sudan found that $68 \%$ of respondents were not satisfied with government provision of education services (IRI, 2013, cited in Novelli et al., 2016, p. 44). This undermines post-CPA promises and expectations of 'peace dividends' in the form of increased access to social services. This can, in turn, undermine community perceptions of government legitimacy linked to quality-of-service delivery and statesociety relations (Novelli et al., 2016). Research suggests that fostering future stability in South Sudan will require concerted efforts to improve the government's capacity for public service provision (McCrone \& the Bridge Network, 2021).

Sources of resilience: Despite repeated cycles of violence, and the destruction and weaknesses that it has produced, there remains enduring spaces of 'civicness' - whereby ordinary people are able to push for positive social change and accountability (de Waal et al., 2017). While chiefs have often been seen as a key example of civic authority, it is also important to look to other actors and spaces where civic values persist and can be fostered. These include religious leaders and spaces, teachers and classrooms, lawyers, community councils, and community-based associations (ibid.). For example, as a primary influence on young people outside of the home, teachers, and the education sector more generally, can play a key role in conflict prevention and mitigation (Reisman \& Janke, 2015).

\section{Part I: Education in South Sudan and (in)stability}

\section{Politicisation of education, impact of conflict, and budget shortfalls}

\section{Summary: Redistribution and recognition}

The education system can produce or exacerbate conflict through: policies and practices that deny education to certain groups; manipulation of the curriculum and learning materials; and geographic, ethnic, or gender-based discrimination and marginalisation.

Redistribution: Exclusionary practices in education can be traced to colonial policies and practices, which concentrated resources primarily in northern Sudan and then, in the south, among the Equatorians, with lower provision of services in the Upper Nile and Bahr el Ghazal areas (Duany et al., 2021). Recent research finds that the low investment in education is negatively associated with conflict (Kuol \& Oringa, 2021). Further, political elites often send their own children abroad for higher quality education or to private schools within South Sudan, resulting in little incentive for public investment in the South Sudanese education system (Raza et al., 2019; Daoust, 2018). Recent school closures due to COVID-19, and the establishment of radio instructional programmes with limited coverage, have also excluded millions of children in rural areas (Mayai, 2021). 
Recognition: A key driver of instability in South Sudan has been the imposition of a hegemonic culture through the education system in a very diverse country (Raza et al., 2019). Depending on the ruling government, the language of instruction and privileged religion has alternated between Arabic and Islam and English and Christianity (Vanner et al., 2019). Since the signing of the 2005 CPA, official policy promotes mother-tongue (MT) education; however, teaching and learning resources in MT are scarce and the existence of over $60 \mathrm{MT}$ languages makes the policy challenging to implement (ibid.).

\subsection{Politicisation of education}

In South Sudan (as elsewhere), the education system is a key social and political institution, which can reproduce or positively reshape relations of power, privilege, and inequality that entrench patterns of violence and conflict (Dauost 2018). The education system in Sudan has historically been highly politicised, subjugated to the political interests of state elites and excluding and disempowering the people of South Sudan (Ibreck et al., 2021; Vanner et al., 2019). Depending on the ruling government, the language of instruction and privileged religion has alternated between Arabic and Islam and English and Christianity (Vanner et al., 2019). Exclusionary practices in education can be traced to colonial policies and practices, which concentrated resources primarily in northern Sudan, and then in Equatoria (southern South Sudan), with lower provision of services in the Upper Nile and Bahr el Ghazal areas, populated predominantly by agro-pastoralist groups (Duany et al., 2021). This aimed to reproduce social and cultural differences within South Sudan and to entrench differences between the southern provinces and the northern, Arabic-speaking, Muslim areas of the country (ibid.).

After 1972, the education system was for the first time managed by South Sudanese officials. The 1970s saw the establishment of the first universities in South Sudan. Data suggest that primary and secondary enrolment and school numbers, including for girls, increased significantly (ibid.). This progress was undermined, however, by the legacies of colonialism and violence, including the issue of language of instruction. In order to balance the importance of MT languages and the establishment of national unity, the government adopted a complex language policy: English was the medium of instruction at secondary level, Arabic at intermediate/junior secondary, and primary schools taught a mix of Arabic, English, and MT languages, which varied between rural and urban areas (ibid.). This complex system was not matched with adequate teaching resources to carry it out, and ultimately it confused and undermined individual educations (ibid.).

A key driver of the war that led to the independence of South Sudan was the imposition of a hegemonic culture through the education system in a very diverse country (Raza et al., 2019). During the 1983-2005 war, which ended a decade of government expansion of educational provision in South Sudan, the central government tried once again to use the education system to impose a unified culture on Sudan.

In addition, young people's educations were affected by displacement and military recruitment strategies (Duany et al., 2021). The disintegration of the education system resulted in the proliferation of new education actors, resulting in teachings in different languages and different curricula, often borrowed from neighbouring countries (ibid.). At the same time, displacement in the 1980s and 1990s to refugee camps in East Africa provided some continuity of educational opportunities for South Sudanese. Some South Sudanese even travelled to refugee camps in order to access education (Epstein, 2012). 
Following the signing of the CPA, English and Christianity became the official language and religion within the curricula, ending the oscillation with Arabic and Islam, but they remain sites of struggle and resistance (Novelli et al., 2016). Many teachers have been trained in Arabic and are unable to effectively deliver the new curriculum in English, and many students are unable to speak either Arabic or English (Skårås et al., 2020; Novelli et al., 2016). Official policy promotes MT language education, but teaching and learning resources in MT are scarce and the existence of over 60 MT languages makes it challenging to implement this policy (Vanner et al., 2019). For further discussion, see section ' 5.2 Diversity'.

Despite the many challenges, the transitional period (2005-2011) after the conclusion of the CPA witnessed significant improvement in access to education (Mayai, 2021). Governments and donors invested in schools and teacher training programmes. The diaspora and elites also invested in educational programmes in South Sudan, often in their home communities, partly as a way to build authority in these areas despite their physical absence. Such schools created some opportunities for communities to engage with elites and hold them accountable (Pendle, 2021).

Access to education has deteriorated, however, since independence in 2011 and to a markedly greater degree after the eruption of violence in 2013 (Mayai, 2021). In addition to ongoing challenges with language in education, other legacies, such as the links between education and ethnicity, militarism, and displacement, continue to influence the education system (Duany et al., 2021).

The poor quality of schools and teaching in South Sudan (a result of long histories of neglect) means that superior education is still obtained by travelling outside of South Sudan (whether to refugee camps or to other schools in neighbouring countries) (Daoust, 2018). The shortage in government funding transfers the responsibility for education to households, upsetting statesociety relations (ibid.). Access to education is also vulnerable to economic downturns. Economic decline since 2013, and high levels of inflation, has wiped out the savings of many Sudanese and opportunities for education (Diing et al., 2021).

\subsection{Effects of conflict and inadequate investment in education}

Throughout decades of war, education programmes and curriculums in South Sudan have continued to be developed. These have included community-led education initiatives, as well as rebel organised education. Many South Sudanese people also sought educational opportunities in refugee camps in East Africa during the 1990s and 2000s. Schools across the border included rebel-run schools. While many South Sudanese people fled to escape the war, they also intentionally moved to access education (Epstein, 2012). Following the CPA, many refugees returned to South Sudan and formed an educated class, obtaining work in government and with NGOs. Many also volunteered as teachers. The impact of education on people's ability to socially and economically reintegrate on return significantly varied (Akoi \& Pendle, 2020).

At the same time, conflict had a significantly negative impact on the education system in South Sudan in terms of the functioning and governance of schools (Ibreck et al., 2021; Buchanan et al., 2019). In relation to the latest conflict, by 2017 , only $59 \%$ of schools were open compared to the previous assessment in $2013 / 2015$, and of those, $50 \%$ had temporarily closed (see lbreck et al., 2021, p. 9). Approximately $31 \%$ of primary schools were estimated to have suffered at least one or more attacks since December 2013 and $25 \%$ of schools were 'nonfunctional', while some schools are occupied by armed actors and used as military barracks 
(ibid.; Buchanan et al., 2019). An estimated 17,000 children had been recruited into armed groups (lbreck et al., 2021, p. 9). Some teachers had also joined the army or fled into exile - and others have been killed (lbreck et al., 2021; Buchanan et al., 2019). Widespread displacement has also interrupted schooling (Buchanan et al., 2019).

Other indicators suggest a growth in enrolment. Between 2014 and 2018, the number of pupils registered in the FCDO-funded Schools' Attendance Monitoring System rose from 928,000 in 2014 to over 1.7 million in 2018 (GESS, 2018a, p. 1). The cost of education also increased, however, with a GESS household survey demonstrating that the cost of education for guardians was 2.2 times higher in 2018 compared to 2016 (GESS, 2018b, p. 2). Nonetheless, education remained a priority for households (GESS 2018b).

A massive shortage of teachers, specifically trained and female teachers, and scarcity of learning materials, stemming from the ongoing conflict, are key challenges in the education sector (Vanner et al., 2019). The teacher-student ratio varies from 1:14 to 1:100, with only $9 \%$ female teachers, and 54\% of all teachers untrained (MoGEI, 2017, cited in Skårås et al., 2020, p. 221). The economic impact of the conflict also means that for many families, education is now unaffordable (Buchanan et al., 2019).

The lack of trained teachers and quality education can also increase the importance of patronage and networks. Research on Sudan reveals how education expansion, alongside a lack of quality education, forced employers to rely more on recommendations through networks and not educational qualifications (Mann, 2014). This may also apply in the case of South Sudan. In addition, there are reports of widespread nepotism (often along ethnic lines) and corruption within the education system, with salaried positions at the national, state, and payam levels offered based on past affiliation with the SPLM/SPLA (Reisman \& Janke, 2015). In such contexts, false transcripts and education certificates were not uncommon, making it difficult to ascertain potential teachers' true level of schooling and knowledge (ibid.).

South Sudan currently has some of the world's lowest indicators for education (Raza et al., 2019; O'Grady, 2017). Areas most affected by conflict typically had the lowest number of students in primary education and limited secondary provision (lbreck et al., 2021). Recent research shows that the conflict had reduced primary school enrolment by at least $80 \%$ between 2013 and 2016, with the worse effects observed for boys (Mayai, 2021, p. 10). Based on population projections from census data from the National Bureau of Statistics, $68.6 \%$ of schoolage children in South Sudan are estimated to remain out of school (Clugston, 2018, p. 6).

The extended impact of years of conflict means that many South Sudanese children and young people have missed out, or will miss out, on education, and that learners and teachers may have distinct psycho-social needs resulting from their experiences (Buchanan et al., 2019). Within schools, prior experiences of violence, and parental influence, can affect how students respond to and cope with conflict and diversity, which is increasingly likely given the scale of internal displacement (Novelli et al., 2016). Some primary students described fear, hatred, and conflict between 'newcomer' students and other students, while other students and youth reported that parents may affect conflict dynamics in schools, indicating intergenerational transmission of fear and violence (ibid.). Teachers may also exhibit bias toward particular students, favouring some based on ethnicity or tribe (ibid.). Ultimately, however, conflict within the classroom may be based more on limited classroom resources than specific inter-ethnic conflict between students (ibid.). 
The Government of the Republic of South Sudan (GRSS) has taken some steps to improve the educational system and access to education, including for example, the establishment of an Alternative Education System. This provides a second chance to over-aged children to access basic education (Raza et al., 2019). These efforts have led to a large increase in the number of schools across the country, primarily operated by non-government entities (ibid.).

The Revitalised Agreement on the Resolution of the Conflict in the Republic of South Sudan (RARCSS) of 2018 offers hope for greater stability and improvements in education; however, public investment in education remains low (Buchanan et al., 2019). The percentage of government expenditure dedicated to education declined from $3.23 \%$ in 2013 to only $0.88 \%$ in 2018 (Ibreck et al., 2021, p. 10). While the GRSS has pledged to invest $10 \%$ of the national budget to education, it committed only $5.5 \%$ in the $2019 / 2020$ budget, significantly lower than security and defence spending and the recommended 15-20\% international benchmark for education (Buchanan et al., 2019, p. 4). In turn, acute budget constraints in the education sector have led to the suspension of recruitment and training of new teachers while existing teachers typically receive remuneration below their official grade rates, with salary payments often delayed (Ibreck et al., 2021; Raza et al., 2019). For further discussion, see section ' 6 The role of teachers and key challenges'.

\section{Neglect of the education system in South Sudan is also attributed to different elite}

incentives. Research indicates that political elites often send their children abroad for education, resulting in little incentive for public investment in the South Sudanese education system (Raza et al., 2019). Instead, most funding for education in South Sudan comes through international initiatives; however, international support has also often come up short (lbreck et al., 2021). Private initiatives also play a significant role. In some areas in South Sudan, private schools account for the majority of enrolment (Daoust, 2018, pp. 120-121).

Recent research finds that the lower investment in education in terms of high studentteacher ratio and student-class ratio is positively associated with occurrence of conflict, whereas investment in education facilities (i.e. drinking water access and access to latrines) is negatively associated with conflict (see Figure 2) (Kuol \& Oringa, 2021). These findings indicate that more investment in education is likely to reduce violent conflicts in South Sudan (ibid.).

Figure 2. Link between conflict and education in South Sudan, 2011-2014

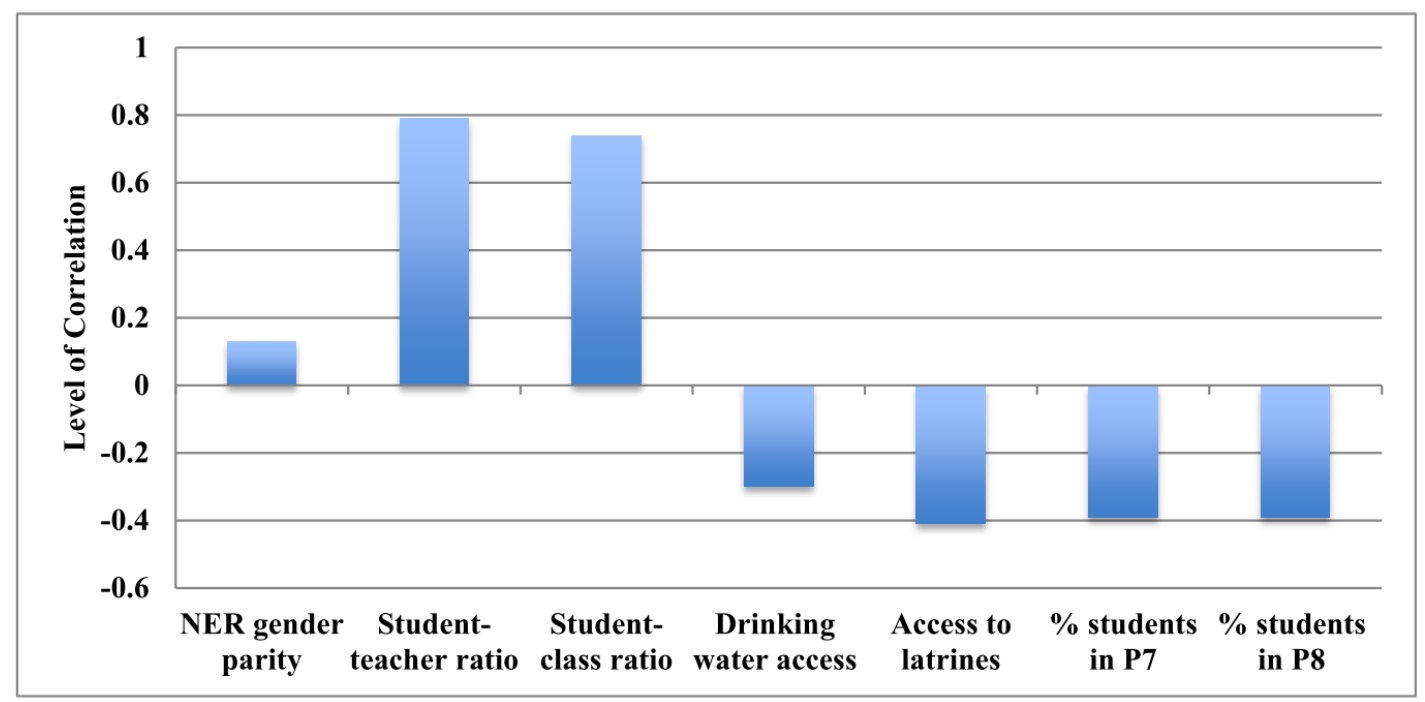


Source: Kuol \& Oringa, 2021, p. 14; based on data from Novelli et al., 2016, p. 38. Reproduced with permission.

The COVID-19 pandemic has compounded problems in the education sector stemming from conflict and poor governance (Mayai, 2021). The closure of schools due to the pandemic resulted in the disruption of schooling for 2 million enrolled primary and secondary school children (UNESCO, 2020). The Ministry of General Education and Instruction (MoGEI), with support from UNESCO, launched Education on Air, a radio education programme in May 2020, broadcasting daily lessons to primary and secondary-level learners, focusing particularly on English, science, and mathematics (ibid.). The radio instructional programme has had limited coverage, however, leaving millions of children in rural areas (representing $80 \%$ of the population) with very limited options for learning (Mayai, 2021, p. 11).

COVID-19-related school closures have also impacted children's access to school meals and increased the risk of drop-out and non-return of qualified teachers to schools. School closures have also placed young girls at higher odds of forced early marriages and pregnancies (Mayai, 2021).

\section{4. (In)equity, exclusion/inclusion, and marginalisation in the education sector}

\section{Summary: Redistribution and recognition}

The education system in South Sudan has produced and exacerbated inequality between different groups in educational access, resources, recognition, representation, and outcomes, which has contributed to pressure for violence (Ibreck et al., 2021; Novelli et al., 2016).

Redistribution: There is wide regional disparity in education enrolment and attainment across states and counties, which correlates with the occurrence of conflict events (Novelli et al., 2016; Reisman \& Janke, 2015). There is no systematic policy, however, to redress these disparities (Novelli et al., 2016). Children and youth in rural areas face greater access challenges due to long distances to school; an inadequate number of schools; and school timetables that conflict with cattle-herding duties (Bul, 2019; Clugston, 2018; Novelli et al., 2016). Girls also face greater challenges, with approximately $75 \%$ of girls unenrolled in primary school, and girls more likely than boys to drop out of school (Toma, 2019, p. 11; Lodou \& Oladele, 2018). When poor families struggle to cover the costs of schooling, they often prioritise boys' education (Duany et al., 2021; Toma, 2019; Novelli et al., 2016). Many wealthy or elite families send their children to study in neighbouring countries where the quality of education is higher, which gives them greater access to employment opportunities (Duany et al., 2021; Raza et al., 2019; Novelli et al., 2016). The privatisation of education services can also contribute to the reproduction of an 'elite' class (Novelli et al., 2016). The long-term risks of exclusion of non-elite classes from education include creating an unskilled generation of young South Sudanese (Mayai \& Hammond, 2014). This can lead to pressures for conflict linked to grievances over access to quality education and employment opportunities and socioeconomic disparities, in addition to susceptibility of those excluded to mobilisation by armed forces (Diing et al., 2021; Novelli et al., 2016; Mayai \& Hammond, 2014).

Recognition: The challenges that female learners face in pursuing an education contributes to low numbers of female teachers to act as female role models for girls, which can negatively 
affect the enrolment and attendance of girls in school (Buchanan et al., 2019). Only $6 \%$ of trained teachers are female (Toma, 2019, p. 11). Curriculum and teaching materials can also play a key role in perceptions and views of girls, boys, women, and men, which in turn can influence attitudes towards schooling (Vanner et al., 2019). Transformative educational materials deliberately depict women and girls in non-traditional gender roles and illustrate them as competent and confident (ibid.). Curriculums may also need to be modified in order to achieve greater cultural and economic relevance for pastoral communities (Bul, 2019; Novelli et al., 2016).

\subsection{Regional disparities}

There is wide regional disparity in education enrolment and attainment across South Sudan's 10 states and across counties within states (Novelli et al., 2016; Reisman \& Janke, 2015). Southern counties were generally characterised by better school facilities and resources, access to education, and outcomes, compared to central and northern counties (Novelli et al., 2016). The probability of completing grade 8 education ranges from $25-43 \%$ in the highest achieving states (Western and Central Equatoria, and Upper Nile) to 11-20\% in the lowest achieving states (Lakes, Jonglei, Warrap, and Eastern Equatoria) (Reisman \& Janke, 2015, p. 3). ${ }^{3}$

Analysis of Education Management Information System and conflict data reveal that states with the highest occurrence of conflict events since 2011 (Unity, Upper Nile, Jonglei) have the lowest provision of educational resources and the lowest percentage of students in upper primary. This demonstrates a relationship between conflict occurrence and inequalities in educational resources and outcomes (Novelli et al., 2016). There is no systematic policy, however, to redress existing and historically driven disparities across geographic areas (ibid.).

Rural-urban disparities: The distances to school in rural areas is challenging for both teachers and students, who often have to travel to school early in the day, returning in the evening (Bul, 2019). Further, during periods of violent conflict, some parents and students may decide that children should remain at home due to insecurity on the way to and from the school (ibid.). In particular, there are concerns about cattle raiding that sometimes takes place near schools (ibid.). School facilities in rural areas are even scarcer at higher levels. According to the South Sudan Schools Attendance Monitoring System (SAMS), a vast majority of the country's already limited 400 secondary schools tend to be situated in urban areas, rendering access to secondary education particularly challenging for children from rural communities (Clugston, 2018, p. 12). For most, accessing secondary education involves not only finding the means to pay for school fees, but also money or networks that allow travel to and residence in urban centres.

Teacher inequities: Teachers experience various inequities, including based on geographic lines. Teacher payment has been used as a tool, for example, in the context of recent conflict, with some interview participants reporting that teachers in opposition-held areas are not receiving salaries (Novelli et al., 2016). In addition, in government-held areas in conflict states, teachers from certain ethnic groups (e.g. Dinka, Shilluk) have received salaries while others (e.g. Nuer)

\footnotetext{
${ }^{3}$ It is not the case that the highest achieving states overlap with the home states of South Sudan's most powerful elites.
} 
have not (ibid.). Salary payment, and the management of education more generally, is seemingly used to 'punish' those said to be associated with the opposition (through ethnicity alone) and to coerce loyalty (ibid.).

\subsection{Gender}

Approximately $75 \%$ of girls are not enrolled in primary school, with even higher disparities in the participation of children with disabilities or those living in very rural and remote areas (Toma, 2019, p. 11). Further, girls that start school are more likely than boys to drop out before completing either primary or secondary school (Lodou \& Oladele, 2018). Only $16 \%$ of the female population over 15 is literate, compared to $40 \%$ of males (de Garang, 2019).

Issues in accessing education stem from the supply and demand side. On the supply side, schools are often far from communities, rendering it challenging for female students and teachers to access due to protection risks travelling to and from school (Toma, 2019). Menstrual hygiene management is also a challenge, as the average cost of a pack of sanitary pads in the capital city, Juba, is equal to almost three days of a teacher's pay (Buchanan et al., 2019; Bul, 2019).

The challenges that female learners face in pursuing an education contributes to lower numbers of female teachers in the present and future - and low numbers of female role models for girls and exposure of boys to female educational professionals (Buchanan et al., 2019). Only $16 \%$ of teachers in South Sudan are women, a ratio that has changed minimally since 2011 and becomes even smaller at the secondary level and among head teachers (ibid., p. 7). Only $47 \%$ of teachers have received training and only $6 \%$ of trained teachers are female (Toma, 2019, p. 11).

While female teachers may not necessarily be more gender sensitive than male teachers, research demonstrates a correlation between the number of women teachers in schools and girls' enrolment (Buchanan et al., 2019). Strategies to increase the number of female teaching professionals could include providing bursaries and other incentives for women to attend teacher training or for their travel and lodging and/or providing quality childcare in or near the school (ibid.). There also needs to be safe spaces for female teachers to meet and to engage with female learners, women representatives in PTAs, and women's rights actors (ibid.).

On the demand side, lack of resources means that poor families commonly prioritise boys' education due to widespread perceptions that educating girls is of less importance (Buchanan et al., 2019; Toma, 2019; Lodou \& Oladele, 2018). Further, cultural beliefs and practices, and strictly delineated gender roles, mean that families tend to rely on girls to do household chores (Toma, 2019; Lodou \& Oladele, 2018). Various studies have also identified early marriage as a key barrier to girls taking up or continuing schooling (Toma, 2019; Lodou \& Oladele, 2018).

While harmful gender norms and stereotypes continue to cause immense harm to women, girls, men, and boys in South Sudan - and limit girls' access to school - the educational system can also be used to deliver gender transformative teaching (Buchanan et al., 2019). The curriculum can play a key role in changing perceptions and views of girls, boys, women, and men (Vanner et al., 2019). Teaching materials, although in short supply in the country, should be reviewed to remove any gender bias and to promote gender equality and diversity through the curriculum (Buchanan et al., 2019; Vanner et al., 2019). A study of textbooks in South Sudan finds some examples of content that seeks to redress inequality and division in terms of gender roles, deliberately depicting women and girls in non-traditional gender roles and illustrating them 
as competent and confident (Vanner et al., 2019). They show women's and girls' ability to accomplish challenging tasks and make use of their strength and resourcefulness, attributes traditionally associated with men and boys (ibid.).

While the focus in South Sudan is often on the difficulties experienced by female learners, male learners also face particular challenges. In some regions, the rate of drop-out for male learners is higher than for female learners (Buchanan et al., 2019). Men and boys can also miss out on school due to obligations relating to cattle rearing, recruitment into armed groups, or seeking employment to help support themselves and their families (ibid.).

\subsection{Socioeconomic inequities}

Contemporary violence in South Sudan is linked to changing patterns of accumulation. These patterns of accumulation have resulted in the rise of new wealthy or elite families who send their children to study in neighbouring countries or at private schools in South Sudan (Duany et al., 2021; Raza et al., 2019; Novelli et al., 2016). The very poorest South Sudanese cannot even afford the cost of travel to refugee camps which might provide some educational opportunities. Employers (government, aid organisations, and private organisations) are more likely to employ young people with foreign credentials from East Africa. NGOs and UN agencies are a major employer in South Sudan and favour education in English, which is often best provided in Kenya and Uganda. This can result in an ongoing reproduction of socioeconomic inequities - and to pressures for conflict linked to grievances over access to quality education and employment opportunities (Novelli et al., 2016). The privatisation of education services also contributes to the reproduction of an 'elite' class with greater access to economic and political resources - and to the marginalisation or exclusion of certain groups, reinforcing existing inequities (ibid.). In 2018, one third of primary schools and over half of secondary schools were private (MoGEI, 2018, p. 16, cited in Duany et al., 2021).

\section{Poor families struggle to accumulate enough money to send their children to school} (Duany et al., 2021). While South Sudan's 2011 Transitional Constitution and 2012 Education Act state that primary education is to be compulsory and free of charge, families must still cover school costs such as contributions to 'school development funds', examination paper fees, uniforms, and materials (Novelli et al., 2016). There are also costs of travel to school. These can be a significant challenge for families and young people living in poverty (ibid.). School capitation grants and feeding programmes, intended to ease families' financial pressures and promote school access, are unlikely to cover all the costs (lbreck et al., 2021; Novelli et al., 2016). Students, who are unable to make all the necessary payments, are dismissed from school (Ibreck et al., 2021). Further, when families cannot cover school costs for all children, boys' education are generally prioritised (see section ‘4.2 Gender' above) (Toma, 2019; Novelli et al., 2016).

\subsection{Pastoral communities}

Challenges associated with access to education and the relevance of school curriculum are particularly significant for 'pastoralist' or cattle-keeping communities (Bul, 2019; Novelli et al., 2016). It is estimated that $70 \%$ of out-of-school children in South Sudan live in pastoralist communities (see Novelli et al., 2016, p. 31). The seasonal migration of pastoralists looking for water and pastures for their cattle makes pastoralist communities very difficult to target with educational programmes; and very few attempts are made (Bul, 2019; Novelli et al., 2016). Education services may not be available due to a general lack of schools in certain 
counties and payams, but also because school timetables and annual school calendars conflict with cattle-herding duties of youth (Novelli et al., 2016).

Barriers to access to education also lie in the cultural and economic irrelevance of formal education and training programmes (ibid.). However, rather than modifying curriculums, organisations operating in affected areas often assume that cattle herders have no interest in education or even in vocational training, contributing to their exclusion (Bul, 2019).

\subsection{Youth}

Much research finds that youth are potential sources of insecurity due to involvement in criminal activities and communal conflict (e.g. cattle raiding), and their susceptibility to mobilisation by politicians and armed forces (Novelli et al., 2016; Mayai \& Hammond, 2014). Rural young men, in particular, lack access to meaningful, quality education, which can force them into more violent livelihoods (Diing et al., 2021). The majority of young people in South Sudan have no primary school education or resources to access education, but have educational aspirations (ibid.). The promise of education has often been used as a strategy to recruit people to armed forces in South Sudan, yet these promises are often not fulfilled.

\section{The long-term risks of exclusion from education include the creation of an unskilled} generation of young South Sudanese. This, in turn, implies potential socioeconomic disparities and persistent risk of instability (Mayai \& Hammond, 2014). A lack of education deepens youth experiences of extreme economic precarity. Youth often survive by relying on insecure incomes from informal sector trade, agricultural production, and work in markets (Diing et al., 2021). In this context, military and security sector work becomes a main opportunity for employment, and to acquire an income and status (ibid.). For education to be an attractive option and alternative to militarised status, higher levels of education and associated income must also be available through, for example, rural scholarships to universities (ibid.).

\section{Unity, diversity, division, and cohesion}

\section{Summary: Recognition, representation, and reconciliation}

Recognition: Prior oscillation between Arabic and English as the main language of instruction occurred at the expense of mother-tongue (MT) languages (Momo, 2021). While official educational policy now promotes teaching in both languages, teachers have generally not been trained to teach them, nor are there yet adequate learning materials (ibid.; Vanner et al., 2019). Educational policy and strategy that emphasise 'South Sudanese identity' can avoid potentially problematic aspects of ethnic identity; however, it prevents the space for teachers and children to teach and learn respect and appreciation of each other despite ethnic differences (Skårås et al., 2020). Textbooks, while containing positive references to shared spaces with newcomers, lack references to communities made richer by ethnic and religious differences - and have few positive references to Islamic or African religions in contrast to many such references in relation to Christianity (Vanner et al., 2019). New textbooks provide an opportunity for materials that address the conflict more thoughtfully (ibid.). There may also be geographic and socioeconomic inequities in terms of student exposure to diverse groups, as school diversity is often greater in urban areas (Novelli et al., 2016). 
Representation: Research finds that education actors at school and payam levels feel their voices and concerns are neglected, potentially limiting recognition of diverse experiences and identities within states - and reproducing patterns of marginalisation within national curricula (ibid.). At the same time, there have been efforts to enhance local-level community participation, particularly through local school governing bodies (Ginsburg et al., 2017).

Reconciliation: Research emphasises the importance of students in South Sudan learning about the geography, history, people, and traditional knowledge of their own country to strengthen connections to the past (Novelli et al., 2016). Critical thinking is a key competency in the curriculum framework, seen as necessary to examine root causes of conflict and to question divisive systems that lead to conflict (Skårås et al., 2020; Vanner et al., 2019). Cooperation is another key competency, which can be particularly important in teaching children to come together across ethnic lines (Skårås et al., 2020). Classroom visits reveal, however, that teachers did not facilitate active participation, critical thinking, and student cooperation in the lessons observed (ibid.). Another study finds that, nonetheless, education can nurture trust among different ethnic groups by allowing for regular interaction, which can reduce fear and stereotypes of the 'other' (Kuol \& Oringa, 2021). There is also anecdotal evidence that efforts to bring teachers together from different warring groups for training activities had a positive impact on relationship building with greater willingness to work together as professionals (Winrock International, 2017). Schools and teachers can also help to provide psycho-social support to students to address trauma resulting from violence (Heltne et al., 2020). At the same time, teachers require psycho-social support themselves in order to be able to effectively support children (ibid.).

\subsection{National unity and cohesion}

The South Sudan National Curriculum Framework (2015) introduced a curriculum that 'is designed to help young people learn about their shared national identity' and 'supports key values for the country including justice, democracy, tolerance and respect' (Maphalala, 2015). Prior to this framework, South Sudan did not have a unified curriculum and many schools borrowed curricula from neighbouring countries (Novelli et al., 2016). Borrowed curricula can, however, lack relevance for students and limits the development of a cohesive national identity (ibid.). Research on South Sudan emphasises the importance of students being able to learn about the geography, history, leaders, and people of their own country, including traditional knowledge and practices, in order to strengthen connections to the past (Skårås et al., 2020; Novelli et al., 2016). There have been some efforts to develop teaching resources specific to South Sudan, such as a revised and updated edition of a secondary school textbook on the history of South Sudan. ${ }^{4}$

At the same time, structural and historic patterns of marginalisation and inequity can be reflected in domestic representations of historical narratives, citizenship, and identity in educational settings (Novelli et al., 2016). Curriculum design and implementation are thus important factors in processes of reconciliation and peace-building, either representing one

\footnotetext{
${ }^{4}$ See for example: Said, A. A., Wawa, Y., Farren, A., \& Breidlid, A. (eds). (2014). A Concise History of South Sudan, Kampala, Uganda: Fountain Publishers.
} 
'official' national history or citizenship, possibly for political purposes, or recognising and legitimising diverse stories, experiences, and identities (ibid.).

The references to 'South Sudanese identity' and 'we' in the curriculum framework are not well defined or understood, however, and the words 'ethnic' and 'ethnicity' are not mentioned once (Skårås et al., 2020; Skårås, 2019). Thus, the curriculum avoids the problematic aspects of ethnic identity (Skårås et al., 2020; Skårås, 2019). Research indicates that this policy and strategy may deter teachers from talking about contentious issues and prevents the space to foster alternative ways of thinking through which children learn to respect and appreciate each other despite their ethnic differences. This, in turn, can obstruct the creation of a national identity and global identity that transcends ethnicity and tribal tension (Skårås et al., 2020; Skårås, 2019). At the same time, ethnicity has been actively reshaped and politicised by decades of war, including through the retelling of histories to mobilise groups to war. The intentional avoidance of 'ethnicity' and the embedded assumption that it is salient to citizenship, can also be seen as an active and thoughtful approach to write a history and curriculum that does not assume the centrality of ethnicity or pre-existing ethnic identities.

\subsection{Diversity}

Curriculum development can instead also present opportunities to formulate inclusive representations of national identity and citizenship that promote cohesion and belonging (Novelli et al., 2016). While it is considered important to ensure that all group identities are found in the curriculum, enabling more students to find themselves in educational narratives is a tremendous challenge (ibid.).

Recruitment of teachers should reflect diversity, with a good balance of male and female teachers from different ethnic groups and with different language skills (see Haider, 2014). In South Sudan, where many teachers are underqualified and lack sufficient training and support, however, textbooks are often the main source of the curriculum (Vanner et al., 2019). A thematic analysis of South Sudan's textbooks for students in Grade 4 Social Studies, English, and Christian Religious Education finds these current textbooks are unlikely to foster meaningful critical thinking or to build social cohesion - and have the potential to cause divisions through marginalisation and stereotyping (ibid.).

Textbooks contain positive references to shared spaces with newcomers, stemming from displacement, demonstrating an effort to encourage a shared national identity. Such efforts are limited, however, by the absence of references to communities made richer by ethnic and religious differences (Vanner et al., 2019). Texts have few explicit references to Islamic or African religions as positive elements of modern South Sudanese society, while many such references are made in relation to Christianity (ibid.). This narrative reinforces the concept of Christianity as dominant and superior, which in turn, can foster divisions (ibid.). The textbooks examined also perpetuate divisive stereotypes. Where explicit references are made to Arab populations, they are positioned as the enemy 'other' - described as deceitful and cruel slave traders - in contrast to the Europeans, referred to as 'our Christian friends' (ibid.).

The ongoing development of new textbooks in South Sudan provides an opportunity for materials that address the conflict more thoughtfully and involve students and teachers in the development of skills essential for peace and social cohesion (ibid.). This requires: recognition of historic divisions, poverty, and inequality; validation of differences and equal representation of men and women in non-traditional roles in both public and private life; and representation of payam and 
county borders, given that the current conflict is linked to local borders and territories (ibid.; Novelli et al., 2016).

Although such an approach to curriculum would require more time and resources, it can facilitate recognition and representation of the significant diversity within states (ethnic, linguistic, geographic, etc.) (Novelli et al., 2016). Importantly, the curriculum should encourage students to reflect on the positive elements of the differences in their society (including ethnic, religious, gender, socioeconomic, and geographic), to engage in critical thinking about factors contributing to conflict, and to consider strategies for living together more peacefully by challenging inequity and developing conflict-resolution skills (Vanner et al., 2019).

The oscillation between Arabic and English as the main language of instruction prior to independence in 2011 occurred at the expense of MT languages (Momo, 2021). This resulted in perceptions by some parents and children, particularly in urban areas of their mother tongue as socially inferior to Arabic or English (ibid.). In addition, those who have their language selected for instruction may also perceive themselves as superior to those whose language has been marginalised (ibid.).

While official policy now promotes teaching in 'national languages', teachers have generally not been trained to each such languages, nor are there yet adequate learning materials (ibid.; Vanner et al., 2019). Even though the language policy states that teaching of national languages terminates at Primary 3 (P3), literature in these languages should be developed beyond primary schools to enrich cultural heritage and foster diversity and inclusion (Momo, 2021). Other ways in which teachers have promoted cultural diversity and reduced tensions is by encouraging cultural practices which bring people together, such as traditional dance where every learner is encouraged to learn from the different tribes (Awany, 2021).

\subsection{Critical thinking and citizenship}

The educational system in South Sudan aims to inculcate a civic-minded worldview amongst its citizens through its curriculum (Wawa, 2021). Critical and creative thinking and cooperation are two of four competencies outlined in the curriculum framework (in addition to communication, and culture and identity). In post-conflict societies, critical thinking is seen as an important way in which to examine root causes of conflict and to question systems and divisions that lead to conflict (Skårås, 2019; Vanner et al., 2019).

Discussions of 'constructive' citizenship in the educational system in South Sudan, particularly at the central level, have focused primarily on legal rights and responsibilities, rather than questions of identity (ethnic, linguistic, religious, geographic, etc.) (Novelli et al., 2016). Such civic education has the potential to promote social, civic, and political engagement among students (Oringa \& Koul Deng, 2021). Efforts to promote open discussion of social and political issues, such as through student debates, are important elements of civic education. Student parliaments and charitable volunteering connected to classroom work have been effective ways of raising student interest and engagement in political and civic issues (ibid.). Recent research finds that these civic-oriented dimensions of education in South Sudan are likely to foster a resilient social contract and sustainable peace, in addition to raising demand for good governance - with students becoming key political stakeholders (ibid.).

There have been limitations in practice, however. It is the role of teachers to interpret such a curriculum. As such, teachers need to be well trained and equipped to teach critical 
thinking, civic skills, and values, which fall outside the traditional method of instructing learners to know or memorise facts (Wawa, 2021). Classroom observations and teacher interviews in South Sudan, from another recent study, reveal that critical thinking is not a universal concept, but rather a foreign concept to the majority of teachers (Skårås et al., 2020). Norms of school-based education in South Sudan have their history in early twentieth-century missionary and colonial schools. Through these schools, South Sudanese school 'education' adopted patterns that excluded critical thinking.

Observed teaching methods do not necessarily encourage active participation and critical thinking as stated in the new curriculum. Rather, student questions were limited and the lack of textbooks and overcrowded classrooms catered more to memorisation and rote learning, than to the development of actively engaged citizens (Skårås et al., 2020). Key challenges include: limited relevant training of teachers to promote critical thinking and civic engagement; limited teaching and reference materials; and a history of extended periods of violence in the country which has normalised violence as a legitimate solution to conflict (Wawa, 2021). In contrast, much informal education in South Sudan does involve problem solving, riddles, and critical thinking.

\subsection{Social capital and relationship building}

The historic use of ethnicity by the ruling elites in Sudan as a basis for accessing power has made many students affiliate more with their ethnic groups (Kuol \& Oringa, 2021). In such a context, schools can play an important role in bringing together members of diverse communities (Novelli et al., 2016).

A recent study finds that education in South Sudan is likely to nurture trust among different ethnic groups by allowing for regular interaction (Kuol \& Oringa, 2021). An overwhelming majority $(78 \%)$ of the students surveyed confirmed their inter-ethnic interaction with other students as very often, particularly among female students (84\%) compared to male students (73\%) (ibid., p. 24). Although the concentration of education in urban centres limits access, urban schools are more likely to be ethnically diverse.

The study also supported the view that education matters in providing a trusted platform for building interpersonal trust and nurturing social capital and social cohesion (Kuol \& Oringa, 2021). This can be achieved through interactions that reduce fear, anxiety, and stereotypes of the 'other' (ibid.). About $62 \%$ of students surveyed confirmed the added value of inter-ethnic interactions in building interpersonal trust, particularly among undergraduate students (72\%) and female students (66\%) compared to male students (60\%) (ibid., p. 25$)$.

Teachers may also promote particular activities, such as playing football, in which every student is encouraged to participate, irrespective of tribe (Awany, 2021). As in other divided contexts, such forms of engagement can contribute to relationship building among participants.

Education also plays a role in bringing together teachers of diverse backgrounds. There is anecdotal evidence that attempts to bring teachers together from different warring groups in South Sudan for training activities had a positive impact. Careful facilitation led to the willingness to work together as professionals (Winrock International, 2017). Such peer learning is valuable in most teacher training contexts, but particularly in conflict-affected and divided contexts (ibid.). Further, despite ethnic cleavages and regional differences, research finds that educators from different contexts can often connect through the discovery of shared 
problems and common agendas that cut across diverse settings and experiences (lbreck et al., 2021). Teachers in South Sudan at present, though, are constrained in their local silos, disconnected from one another, which limits the opportunities for a national approach to education and for the development of united political movements for change (ibid.).

Learning to work together and cooperation is, as noted, a key competency identified in the curriculum in South Sudan. This can be particularly important in divided societies, teaching children to come together across ethnic lines (Skårås et al., 2020). Classroom observation in a recent study reveals, however, student cooperation was not facilitated in the lessons observed (ibid.).

On a larger scale, the benefits of bringing diverse students together in schools may not be distributed equitably. School diversity may be greater in urban schools and in secondary schools, which tend to draw students from different communities (Novelli et al., 2016). As such, there may be geographic and socioeconomic inequities in terms of student exposure to diverse groups (ibid.).

\subsection{Psycho-social support and wellbeing}

School is important not only for children's learning, but also for basic human rights and wellbeing (Heltne et al., 2020). Regular schooling has long been seen as important in providing stability, structure, and routine to children, which can help them to cope with stress (ibid.). Various studies demonstrate that a return to school in conflict-affected contexts reflects an important return to 'normality', providing a protective environment and sense of continuity for children and youth. Schools can also help to provide psycho-social support to students as most experience trauma from violence (ibid.). Teachers and schools are considered to have important roles to play in supporting emotional needs (ibid.). At the same time, teachers themselves also require support for their psycho-social and economic wellbeing in order for them to be able to effectively support children (ibid.). Teachers also need to be trained to recognise the impact of stressors on children, and to learn how to provide psychological support (ibid.).

\section{The role of teachers and key challenges}

Teachers are 'frontline state-builders', who also have the potential to contribute to nation-building in South Sudan through quality of learning and in socialisation of students (Ibreck et al., 2021; Haider, 2014). At present though, teachers in South Sudan remain poorly paid with limited or no training, while working in extremely challenging teaching environments (lbreck et al., 2021; Buchanan et al., 2019). While the government has set a teacher-student ratio at 1:44, in reality it is as high as 1:106 in some parts of the country (Buchanan et al., 2019, p. 7). Access to basic materials, supplies and infrastructure are also constrained, which undermines the creation of an enabling learning environment - and has even resulted in school closures across the country (Buchanan et al., 2019).

Teacher training: Less than half (47\%) of South Sudan's teachers have received formal teacher training, making the national ratio of qualified teachers to pupils 1:171 (see Buchanan et al., 2019, p. 7; Toma, 2019, p. 11; Winrock International, 2017). Only three of the country's seven teacher training colleges are operational, and these are heavily reliant on humanitarian and development partners (Buchanan et al., 2019, p. 7). Moreover, a large number of teachers in South Sudan have not themselves completed their own primary and secondary education. In 
addition, many of the most qualified teachers were educated in Arabic and have had limited opportunity to enhance their own proficiency in English or to receive formal training for teaching in English (Winrock International, 2017). In recognition of the significant proportion of untrained teachers in the primary teaching workforce, the General Education Strategic Plan, 2017-2022 places teacher pre-service and in-service training as priority activities in partnership with development partners (Târlea et al., 2021). A recent study finds that there is a need for more training not only for teachers, but also for head teachers, school inspectors, and PTA members (ibid.).

Other challenges include the absence of a unified teacher registry in South Sudan. Some teachers were on the government payroll and thus fulfilled certain conditions of educational attainment, but a large majority are volunteer teachers, who may receive some compensation from the community and/or the local education authorities (Reisman \& Janke, 2015). There is little transparency, however, in how these volunteers were recruited, trained, supervised, supported, and monitored (ibid.). Research suggests that training for school leaders should include how to best utilise volunteer teachers, including the provision of classroom cover for teachers not in attendance and supporting teachers with overcrowded classes (Târlea et al., 2021). Training is also necessary for volunteer teachers themselves on how to monitor pupil behaviour and understand and implement lesson plans (ibid.).

In conflict-affected contexts, teachers require additional training in order to play a genuine role in transformative education (Buchanan et al., 2019). This requires, for example, training in how to promote critical thinking and specific modules and ongoing support to equip teachers to recognise gender-biases in the curriculum and their teaching practices (ibid.). This should include training on how to recognise and safely respond to sexual and gender-based violence and on non-violent forms of punishment (ibid.).

Teacher absenteeism: Teacher absenteeism, which is a key problem in South Sudan, wastes valuable financial resources and undermines learning for students (Târlea et al., 2021). Lack of pay is the most frequently reported reason for being absent from school among public school teachers, reflected in various research (ibid.). To feed their families, teachers need to engage in other livelihoods to survive. Other key barriers to attendance and punctuality include distance to school, weather, and community infrastructure - including poor-quality roads and lack of public transportation options (ibid.)

In 2018, a survey of 400 primary schools in the country found $30 \%$ of teachers not in school on the day of visit, consistent with figures from the prior two years (ibid.). A recent study finds that more than half of surveyed teachers $(53 \%)$ reported experiencing at least one form of absence once a week or more, resulting in less time spent teaching than planned (ibid., p. 7). Female teachers were more likely to report being regularly absent from school and losing teaching time in the classroom than male teachers, with health reported as a key reason for absence (ibid., p. 7). Inadequate school infrastructure and lack of teaching materials such as chalk, textbooks, and visual aids were also cited as reasons for loss of planned teaching time (Târlea et al., 2021). 


\section{Part II: Donor Involvement in Education in South Sudan}

\section{Modes of engagement}

State institutions are rarely the sole providers of education, particularly in contemporary protracted conflict settings, as in the case of South Sudan (Ibreck et al., 2021). Schools cannot simply be categorised as either state-provided or private, since education is neither predominantly delivered, funded, and managed by the state, nor is it simply being 'privatised' (ibid.). Rather, government officials, schools and teachers, private actors, international and local donors, agencies, NGOs, community leaders, and volunteers have all contributed to the delivery of education (ibid.). This reality was reflected in the national General Education Strategic Plan, 2012-2017, which acknowledged that much of the management of education in South Sudan has been in the hands of development agencies and civil society organisations (O'Grady, 2017). Out of 6,000 schools operating in South Sudan in 2017 , only $60 \%$ were governmental and the remainder were run by communities, NGOs, faith-based organisations, and for-profit providers (Ibreck et al., 2021, p. 9).

The various activities and interactions between these multiple actors and the important role played by non-state actors and networks shape forms of local governance and political order in South Sudan (lbreck et al., 2021). The fragmentation of the education sector can in some cases be seen as a potential source of tension, particularly in the case of geographic fragmentation (Novelli et al., 2019). Schools in displacement sites, for example, especially the UN Protection of Civilian ( $\mathrm{PoC}$ ) sites, are singled out as presenting particular challenges (Ibreck et al., 2021). In addition, the divergence between government schools and 'private schools' is seen to be associated with rising differences and inequalities and the emergence of a parallel system of education, with different curricula, teacher training programmes, and management approaches (see ibid.; Novelli et al., 2016). Ministry of Education, Science and Technology (MoEST) officials perceive some humanitarian actors' approaches to service provision as overshadowing or bypassing the government, potentially undermining community perceptions of government legitimacy (Novelli et al., 2016).

Local populations in some cases also perceived service delivery by NGOs and funded by donor governments, covering specific geographic areas or zones, to be reminiscent of former colonial systems of administration (Brophy, 2020). Some research finds, however, that parents and communities in fragile contexts often supported donors bypassing central administration, as they perceived inequality in the provision of education as an underlying cause of conflict stemming from self-interested behaviour at the central level (ibid.).

Some international development donors channel resources directly to local authorities, such as county governments, while supporting institutional capacity development at central and state levels (Novelli et al., 2016). One component of the GESS programme, for example, supports decentralised service delivery through school capitation grants (ibid.). While this can strengthen local service delivery and participation, some have argued that it can contribute to tensions between central and local governments, potentially undermining state legitimacy at the national level (ibid.). Yet, in a context where central government has regularly struggled to distribute funds to a more local level, directly working with local governments has ensured that funds have reached schools. Further, in many conflict-affected communities, including opposition-held areas, humanitarian and donor interventions are necessary as the government and by implication MoEST education services - is viewed with hostility (ibid.). Government 
services may also be seen to reflect limited representation and recognition of diverse ethnic communities and political perspectives, linked to broader dynamics of political, economic, and cultural exclusion (ibid.).

School-based resource allocation by donors often take into consideration 'conflict-sensitive' criteria, reflecting knowledge of resource-related tensions and conflicts. There is still, however, the risk that donor resource distribution approaches may further entrench patterns of marginalisation and exclusion for particular population groups and geographic communities (Novelli et al., 2016). Payam education officials and school managers and teachers in different states have expressed frustration when government or development partners engage only with state and county authorities. They feel that their voices and concerns will not be adequately represented (ibid.).

It is essential that the active encouragement of communities to participate in the education sector be matched with appropriate levels of material and financial resources (Ginsburg et al., 2017).

Should donors fail to provide participants with the necessary means to implement their role and tasks, they may become disillusioned with the concept and process of participation (ibid.). Recent cuts in the UK government's overseas aid have influenced the implementation of consortium activities under GESS. Teacher training and a mentorship scheme for girls in Bor city, for example, run by consortium member Windle Trust International, was cancelled just prior to the start, after almost 2,000 teachers had signed up (Sparks, 2021).

\section{Interaction of donor interventions with conflict dynamics}

\section{Summary: Redistribution, recognition, representation, and reconciliation}

Redistribution: The distribution of international partners across geographic locations and education resource allocation is considered, in some cases, to have fuelled and reinforced geographic inequities and contributed to pressures for conflict (Novelli et al., 2016). Teacher training, for example, is often centred in 'safe zones' or urban areas, leaving some of the most disadvantaged parts of South Sudan, including conflict-affected areas, with few to no teacher training options (Buchanan et al., 2019). At the same time, donors have generally been aware of the potential for resource distribution to contribute to community tensions, adopting conflictsensitive criteria for resource distribution (ibid.).

Research suggests that GESS cash transfers have contributed to a significant increase in the proportion of girls enrolled in school (Ibreck et al., 2021; Jo, 2019; Clugston, 2018). More than half of school-age girls remain out of school, however, due in part to the inability of the cash transfers alone to offset other barriers to education. These include physical dangers in travelling to school and the ongoing practice of early marriage for girls (Clugston, 2018). The GESS radio programming seeks to present different portrayals and representations of girls and of gender that are not focused on domestic duties and on marriage (Bul, 2019).

Recognition: While GESS radio programmes, aimed at awareness-raising and behavioural change, have been broadcast in nine languages, this falls short of accounting for all of the over 60 languages (GESS, 2020a). Visual storytelling print resources have also been developed in such a way that community mobilisers can go through them in their own 'national language' (GESS, 2020a). Donor programming has also incorporated gender-responsive teaching; for example, ensuring that learning materials use male and female examples such that girls see 
themselves represented, increasing their likelihood to engage with education (UNESCO, 2020). The representation of powerful female role models in curriculum content and stories can increase the confidence of girls and change attitudes relating to gender roles (Buchanan et al., 2019).

School curricula also need to be relevant to the cultural and livelihood systems of cattle-keeping and rural communities, such as through the incorporation of cultivation and animal husbandry elements (Novelli et al., 2016) or the application of numeracy - for example, to assist with participation in the cattle trade. In addition, support to schools located between counties, payams, or communities can promote school diversity and reconciliation by bringing together members of conflicting groups (ibid.).

Representation: Development partners may engage more prominently with state and county authorities, which leaves the voices and concerns of payam-level education officials and school managers and teachers possibly unaddressed (ibid.). This can also adversely affect the diversity of views in education policy and planning. However, donors have been involved in programmes aimed at creating capacity for community-level participation, particularly through school-based management (SBM) (Ibreck et al., 2019; Winrock International, 2017). Research on Room to Learn and the Oxfam ALP finds that school communities surveyed had established PTAs, with strong female representation (Nicholson, 2018; Winrock International, 2017). In the case of the Oxfam ALP, PTA members have visited cattle camps to re-engage learners and have also encouraged young girls to attend ALP (Nicholson, 2018). PTAs reviewed in the Room to Learn study, however, were either inactive or minimally active, due in part to lack of capacity (Winrock International, 2017). In the case of the GESS programme, there are concerns that since the establishment of a PTA or similar governing body is a key requirement for schools to be eligible for receiving a GESS grant, PTAs may be created solely for this purpose and exist in name only (Kang, 2017).

Reconciliation: In South Sudan, where geographic boundaries are often indicative of social and ethnic tensions, bringing together representatives from different states in education sector planning has facilitated awareness of commonalities (Diaz-Varela et al., 2016). In addition, research on SSTEP finds that teachers should be trained in understanding and addressing topics of human rights, citizenship, reconciliation, conflict dynamics and transformation, identity issues, non-violent alternatives, and historical memory (Reisman \& Janke, 2015). Even if training is focused on traditional subject matter (e.g. English and mathematics), conflict-sensitive messages should be integrated into these subjects (ibid.). Research on Ibba Girls' School, which seeks to educate girls such that they can contribute to maintaining peace and advocate for human rights, finds that girls who attend the school report developing respect for other people and helping to stop quarrels (Philip et al., 2019).

\subsection{Inequity/equity, marginalisation, and exclusion/inclusion}

\subsubsection{Regional disparity}

The distribution of international partners across geographic locations affects education service provision and perceived inequities (Novelli et al., 2016). In some cases, education resource allocation is seen to have fuelled and reinforced geographic inequities and contributed to pressures for conflict (ibid.). After large-scale conflict erupted in December 2013, donors pivoted their spending away from development activities and towards humanitarian aid that was targeted at the most in-need. For many donors, this significantly impacted the amount and form 
of spending on education, although some large education programmes - such as GESS - did continue. Education was included in the humanitarian response, and spending on education through this response focused on areas with the most humanitarian need.

For example, education cluster humanitarian activities were concentrated primarily in Unity, Upper Nile, and Jonglei states in 2015 as they were considered to be areas most affected by conflict. This led to frustrations, however, among authorities and communities in 'stable' (i.e. Equatorial) states, based on perceived exclusion from resources. There was also the sense that these recipient states were 'rewarded' for violence (ibid.). At the same time, spending on education from longer-term funds often struggled to access the most conflict-affected regions as they required basic infrastructure, phone signal, and bank account access. This was impossible for many schools in the most conflict-affected areas, especially those under opposition control.

Donor resources may also be allocated based on the presence of NGOs or other implementing partners in specific areas, which may be concentrated in particular states or counties. States or counties with multiple NGOs providing services and resources, such as learning materials or latrines, receive the same government budget as those without NGO support (ibid.). This can then result in perceptions of inequity in resource distribution and actual disparities across locations (ibid.). At the same time, donor and government representatives were generally aware of the potential for resource distribution to contribute to community tensions and aimed to adopt conflict-sensitive criteria for resource distribution (ibid.).

Recent research finds that one of the key achievements of the GESS cash transfer programme has been the establishment of a mechanism to deliver government and donor funds to elementary schools in areas occupied by anti-government militants (Jo, 2019). GESS programme staff have sought to deliver funds in a conflict-sensitive way. For example, in Unity State, funds for primary schools in government-held areas at one stage had not reached schools due to abrupt governance changes that left a vacuum in state structures. There was thus a risk that GESS payments in opposition areas could exacerbate divisions if schools in government-controlled areas were deprived of funds (Hodgkin \& Thomas, 2016). As such, GESS in this particular case made payments in government and opposition areas simultaneously, also funding 58 primary school grants in government-controlled areas (ibid.).

As discussed above, rural areas often suffer from inadequate access to schools. In addition, there are concerns that radio schooling programmes (e.g. those established after school closures due to COVID-19) and radio programmes aimed to achieve changes in attitudes and behaviours fail to reach rural populations. The GESS radio programme, for example, is limited in its reach since students and parents who live in poor, rural areas do not have access to the show (Jo, 2019). As such, it could be preferential for educators to focus on regular education conferences from region to region so that all school students can access the radio programmes (ibid.).

\subsubsection{Gender and socioeconomic inequalities}

Education policy and programming have selectively engaged with aspects of inequality. Following global education agendas, gender and primary education have been a focus (Novelli et al., 2016). Research emphasises, however, that there has been inadequate attention to underlying historical systems and structures of cultural, political, and economic inequities (Daoust, 2018). The focus on primary education, to the exclusion of secondary and post-secondary education, results in much greater restrictions in access to higher levels of education and employment opportunities, exacerbating exclusionary class systems. 
Research conducted directly by GESS and independent impact analysis find that the GESS cash transfer programme has contributed to improving gender equality within schools by increasing the enrolment and attendance of girls in grades Primary 5 to Secondary 4 (P5S4) across South Sudan (Clugston, 2018). Despite the low values of the transfers, they helped to ease the financial pressure felt by South Sudanese families, particularly in the context of ongoing economic decline (Cambridge Education, 2020; Clugston, 2018). The financial support encouraged families to send girls back to school by helping to cover some of the costs of attending school, such as fees, uniforms, and learning materials (Ibreck et al., 2021; Jo, 2019; Clugston, 2018).

Research suggests that GESS cash transfers contributed to an increase in the proportion of girls enrolled in school from less than 40\% in 2014 to $44.4 \%$ in 2017 and to $46.06 \%$ in 2018 (Clugston, 2018, pp. 3, 8; Jo, 2019). In 2019, school enrolment stood at 1.98 million pupils, $45.3 \%$ of them girls. These national records were achieved in the context of mass displacement from the ongoing conflict (Cambridge Education, 2020). Since there were no other major programmes focused on increasing girls' enrolment, there is a greater possibility to attribute the increase in girls' enrolment to the GESS programme (Clugston, 2018).

\section{GESS cash transfers and capitation grants also made it more likely that schools would} remain open despite the risks of ongoing levels of violence and conflict (ibid.). Data reveal that schools that received capitation grants increased their enrolment the following year by between $7 \%$ and $8 \%$; and schools that received cash transfers increased their enrolment by between $8 \%$ and $9 \%$ the following year (Crawfurd, 2017, p. 1). As such, while GESS targeted increased enrolment of girls in schools, it also had the effect of increasing attendance rates in general (Clugston, 2018). This, in turn, can contribute to the general wellbeing of children, providing them with a regular safe space to interact and learn. GESS also provided funding for the reopening of schools after more than a year of closure due to COVID-19, enabling distribution of water, sanitation and hygiene supplies, thermometers, reusable masks, and menstrual hygiene management kits (Xinhua, 2021).

Despite the positive impacts of the GESS cash transfer programming, a high percentage of school-age girls are still not enrolled in school. It is unclear, however, why the transfers have been inadequate as an incentive for more girls to enrol (Clugston, 2018). Payments may be delayed in some cases due to distance, particularly to rural areas (Ibreck et al., 2021). Schoolage girls may also remain out of school if the value of the cash transfer is seen as inadequate to offset various other costs and risks associated with sending girls to school, such as physical dangers in travelling to school (Clugston, 2018). In the case of secondary schools, limited employment prospects may also undermine the perceived value of secondary education (ibid.). Moreover, some communities may face higher opportunity or perceived opportunity costs when sending their girls to secondary school, specifically in relation to societal roles, responsibilities, and expectations placed on girls as they get older to get married (ibid.). Research conducted by UNICEF finds that while $9 \%$ of girls in South Sudan were married by the age of 15 , this increased to $52 \%$ by the age of 18 (see ibid., p. 11).

GESS also uses the radio to promote social and behaviour change towards education. Its radio programme, Our School, has sought to challenge social and behavioural barriers to girls' education, relying on local experiences and stories (GESS, 2020d; Jo, 2019). Episodes have emphasised the advantages of staying in school, sought to challenge particular gender norms and myths about education, and highlighted the role that parents and communities can play in supporting their children's education, particularly that of girls (GESS, 2020d). It is vital that social 
and behaviour change campaigns provide different portrayals and representations of girls and of gender that are not focused on domestic duties and on marriage (Bul, 2019).

Through its radio programming and community mobilisation programme, GESS has sought to address the entrenched social and cultural norms of the role of girls as wives and mothers, in charge of domestic work, diminishing the prioritisation given to their education by parents (GESS, 2020a). Research suggests that over $50 \%$ of people participating in community mobilisation are taking some type of action that supports girls' education (ibid., p. 1). Radio programming and community outreach have been paired with mentoring activities, engaging with sensitive topics related to education for girls (GESS, 2020a). Training was provided to the girls who became peer mentors (GESS, 2020c).

While radio programmes have been broadcast in nine languages, this falls short of accounting for all 'national languages' (GESS, 2020a). Visual storytelling print resources have thus also been developed in such a way that community mobilisers can go through them in their own 'national language', in addition to local community drama activities (ibid.).

With regard to curriculum and learning materials, UNESCO's training programme to strengthen the capacities of teachers in South Sudan to deliver quality education over the radio, during COVID-19 school closures, included attention to gender-responsive teaching (UNESCO, 2020). This included, for example, ensuring that learning materials and language are inclusive, using male and female examples - such that girls see themselves represented in the curriculum, increasing their likelihood to join radio education (ibid.).

The representation of powerful female role models in curriculum content and in media stories is also a way in which to encourage the education of girls, increasing the confidence of girls and changing attitudes relating to gender roles (Buchanan et al., 2019). Oxfam, with funding from Danida, has produced a storybook, The girl who fought for freedom and other stories of courage, which showcases powerful stories of South Sudanese women leaders, including that of a teacher who serves as a role model to female students (ibid.). These storybooks are to be distributed in schools as learning materials for gender transformative teaching (ibid.).

\subsubsection{Pastoral communities}

The focus given to girls' education in global education agendas, and specifically in donor policies and programming, means that other marginalised groups may be excluded from redistributive programming (Novelli et al., 2016). These include pastoralist communities and older youth. It is important to ensure that school curricula are relevant to the cultural and livelihood systems of diverse communities, such as cattle-keeping and rural communities and to their specific needs, such as scheduling constraints. If not, formal education can contribute to instability through the enforced changing of livelihoods and the separation of children from families (Daoust, 2018). Curriculum modifications could involve the incorporation of cultivation and animal husbandry elements into both formal and non-formal curricula, along with elements of informal or traditional learning prioritised by communities (Novelli et al., 2016). Education experiences and curriculums for cattle keepers could support skills for their livelihoods, such as numeracy to assist with their participation in the cattle trade. 


\subsection{Diversity}

Alongside gender representations in learning materials and curricula content that incorporates learning relevant to pastoralist learners, diversity in teaching can also include different languages. Oxfam's Accelerated Learning Programme in Greater Ganyliel, for example, has put in place enhanced mother-tongue (Nuer) literacy for level 1, providing books, charts and teaching aids, and training to teachers to improve teaching methodology and outcomes (Nicholson, 2018). Assessments of the programme find that it has contributed to a $28 \%$ improvement in Nuer literacy (ibid., p. 13).

Support to the construction, maintenance, and running of schools located between counties, payams, or communities is another way in which to promote school diversity and reconciliation by bringing together members of conflicting groups (Novelli et al., 2016). UNICEF has supported the construction of schools along borders between conflict-affected payams in Tonj East County, for example (ibid.).

\subsection{Decentralised and inclusive participation}

Research finds that donors and the government have been involved in programmes aimed at creating capacity for community participation and in encouraging community involvement (lbreck et al., 2019). School-based management has become a popular approach under decentralisation to stimulate, focus, and guide the involvement of community members around the governance and management of their local school (Winrock International, 2017).

While central and local government officials should engage directly with school governing bodies to strengthen vertical relationships, education actors should also coordinate with parents and community leaders such that they are engaged in the development of curricula, materials, and teaching methods (Buchanan et al., 2019; Novelli et al., 2016). This is facilitated, in particular, through building the capacity of and working with school management committees (SMCs) and PTAs as critical links between the school and the community (Buchanan et al., 2019).

Donors have incentivised this participation and SBM through support to school financing, sending money directly to schools as capitation grants; for example, under the GESS programme (lbreck et al., 2019). This has influenced practices within schools and helped to ensure that most had a SMC or PTA by 2017 (ibid.). There are concerns, however, that since the establishment of a PTA or similar governing body is a key requirement for schools to be eligible for receiving a GESS grant, PTAs may be created solely for this purpose and exist in name only (Kang, 2017). They may lack the functional, autonomous, and participatory characteristics required to serve as an accountability mechanism in a decentralised context (ibid.).

Head teachers surveyed as part of research on Room to Learn reported that all school communities had PTA executive committees, and that in a vast majority of cases they included female members; many of them also indicated that the PTA was either inactive or only active to a limited extent (Winrock International, 2017). This was attributed in part to lack of capacity, as in most communities PTA members are illiterate, with limited education. As such, some found it difficult to engage with the training workshops and had difficulty understanding the complex grants mechanism (ibid.). Even after training, which did increase participant knowledge of issues of gender, social inclusion, and emergency/disaster preparedness, PTA members may have trouble grasping their role, particularly as PTA tasks can overlap with those of the SMC (ibid.). Although the Room to Learn project attempted to coordinate with the GESS programme, 
which worked with SMCs, having two programmes may be confusing at the community level (ibid.).

Other research on community monitoring in relation to teacher attendance, based on interviews with community, school, and local government representatives, finds that in some cases, parents had either observed teacher absences during a school visit, or were informed by their children, and raised the issue with either the head teacher or payam office through the PTA (Târlea et al., 2021). In many other cases, however, interviewees reported little or no engagement from parents and the community on the issue of teacher attendance (ibid.). This was attributed in part to low education levels in the community, which made parents reluctant to engage with more educated teachers and school staff, and to having inadequate time to play a role in monitoring (ibid.).

Research on the Oxfam ALP finds instead that a key strength of the programme has been the establishment, training, and activities of the PTAs, which have strong female representation (growing to 63\% in 2018) and are effective in mobilising communities and increasing reenrolment of ALP learners (Nicholson, 2018). PTA members have visited cattle camps to reengage learners and have been very active in encouraging young girls to attend the ALP with messages to prevent early and forced marriage (ibid.). The PTA was less successful, however, in enforcing teacher attendance, with supervision of teachers conducted more by head teachers (ibid.).

Research on Time to Teach, focused on the issue of teacher attendance, finds that strong school leadership and management, in particular by the head teacher, is considered to be a key influence in teacher practices, including attendance, even in resource-constrained environments (Târlea et al., 2021).

In addition, the GESS real-time data management information system, designed and rolled out with the MoGEI - the South Sudan Schools Attendance Monitoring System (SSSAMS) ${ }^{5}$ tracks student attendance using an SMS reporting system. It is used by national, state, and county officials, partners, and schools to support the management of schools and the allocation of resources (Clugston, 2018). By requiring enrolment and attendance reporting, the SSSAMS contributed to ensuring schools focused on registering students and managing attendance, effectively promoting a culture in schools where enrolment and attendance are considered important by both students and teachers (ibid.).

Head teachers, teachers, and PTA executive committee members have also been primarily in charge of producing school development plans (SDPs), which include in the case of GESS a checklist of items they 'planned' to do with the resources provided through capitation grants (Ginsburg et al., 2017). Students and other community members had played less of a role in the processes (ibid.). Teachers, however, did not have a physical copy of the SDP, which resulted in a duplication of efforts when Room to Learn worked with the same school communities, in terms of developing a plan again. Room to Learn's approach went beyond GESS's school development planning approach by engaging a broader set of community members (e.g. also including children, youth, and women) in discussions about their vision and priorities for improving and developing the school (ibid.).

${ }^{5}$ See South Sudan Schools Attendance Monitoring System (SSSAMS) website. 
Room to Learn and GESS also worked with the MoGEI in drafting The handbook on school governing bodies (MoEGI, 2016). However, it is unclear the extent to which the handbook has shaped the behaviours and actions of education actors, particularly in the absence of any established incentives to promote these (Ginsburg et al., 2017).

\subsection{Critical thinking and notions of citizenship}

Ibba Girls' School has a focus to educate and nurture girls in a safe and secure environment so that they can contribute to the development of their society (including building and maintaining peace and advocating for human rights) (Philip et al., 2019). Research on the school finds that girls who attend the school report developing respect for other people and helping to stop quarrels (ibid.). In addition, school debates encourage skills in being persuasive through language and the ability to listen to and challenge arguments from others in a rational way (ibid.). Some girls also practise their improved skills in English as interpreters. They are asked on occasion to support the local and state government on official business, which raises the girls' confidence and capacity - and reinforces the esteem of the school among local officials (ibid.).

Teachers can also benefit from training in critical thinking and conflict-sensitive education. Research on SSTEP finds that training should be provided by qualified trainers who are aware of conflict dynamics, and that topics should include human rights, responsible citizenship, reconciliation, conflict dynamics and transformation, identity issues, non-violent alternatives, and addressing historical memory (Reisman \& Janke, 2015). With limited teacher education capacity and resources, however, the MoGEI has prioritised a focus on core subjects (English, mathematics, social studies, science, and professional studies) over more conflict-sensitive ones, such as peace-building and human rights. STTEP has followed suit (ibid.).

In order to promote conflict-sensitive education, it is recommended that donors and implementing partners collaborate directly with the MoGEI to identity and agree on a limited number of core conflict-sensitive messages and approaches to be emphasised in teacher training, even if training is focused on pedagogy or subject matter (i.e. integrate conflict-sensitive messages into these core subjects) (ibid.). Alternative delivery mechanisms for teachers to have access to conflict-sensitive topics should also be considered, such as through radio programming (ibid.).

\subsection{Social capital and relationship building}

The participatory nature of education sector planning, such as through the SBM process (see section '8.3 Decentralised and inclusive participation' above), provides an opportunity for education actors to work together on a regular basis to determine priorities and set the agenda for the sector - which, in turn, can foster social capital and social cohesion (Diaz-Varela et al., 2016). In South Sudan, where geographic boundaries are often indicative of social and ethnic tensions, bringing together representatives from different states has facilitated awareness of commonalities and provided an opportunity to share experiences, challenges, and solutions across states (ibid.).

Teacher professional development (TPD) programmes (see also section ' $\underline{8.6}$ Support to teachers' below) should aim to foster a community of learning and collaboration (GESS, 2020b). The GESS TPD programme, for example, facilitated a number of exchange visits between education specialists from different states, where they could meet and learn from one another. Ongoing collaboration was achieved through a Facebook group for education specialists 
(ibid.). As such, programmes designed to support teachers also have the potential to build relationships and social capital.

Methods of teaching and teacher training can also influence relationship building and cooperation among students. Research on Room to Learn finds evidence of socially inclusive classroom practices from classroom observations (Winrock International, 2017). The majority of teachers had adopted key strategies promoted in the Room to Learn workshops, including diverse types of groupings (pair, group, and whole group) of students; cooperative group learning; and calling on boys and girls an equal number of times (ibid.).

\subsection{Support to teachers}

Educational leaders - head teachers and government representatives - have emphasised the importance of ensuring sufficient funding for teachers and the need to make teachers a national priority, recognising the valuable role they play in the development of children and youth (Târlea et al., 2021).

Donors have provided various forms of teacher training. For example, GESS has piloted the TPD programme (discussed above), which seeks to test a model for ongoing TPD with a focus on classroom practices and peer learning (GESS, 2020b). The programme was designed using the findings of the Teacher Needs Assessment, which revealed very low teaching capacity, lack of resources, and inadequate supervision (ibid.). Part of the teacher training content focuses on low-cost and no-cost teaching and learning materials as an important strategy in improving teaching and learning in fragile and conflict-affected contexts (ibid.).

While donor programming has allowed for increases in the amount of training teachers may receive, variations in the level of funding has affected the degree of training. Funding for Oxfam ALP activities was reduced after 2016, for example, which led to the number of teacher training days being reduced from 15 to three; and head teacher days from 10 in 2015 to four in 2018 (Nicholson, 2018, p. 52).

In addition, training opportunities are often centred in 'safe zones' or urban areas, leaving some of the most disadvantaged parts of South Sudan with few to no training options, including hard-to-reach and conflict-affected areas (Buchanan et al., 2019). Where opportunities do exist, they are frequently one-offs or short-term, unsustainable, and only partly coordinated between partners (ibid.). Development partners should coordinate their support to teacher training in order to create synergy among various training schemes and avoid duplicating efforts (Târlea et al., 2021). Promoting equity in education through representation requires that training programmes include and target marginalised communities, including teachers from rural and cattle-keeping communities (Novelli et al., 2016).

\section{References}

Akoi, A. D., \& Pendle, N. R. (2020). 'I kept my gun': Displacement's impact on reshaping social distinction during return. Journal of Refugee Studies, 33(4), 791-812. Retrieved from https://doi.org/10.1093/jrs/feaa087

Awany, J. (2021). Researching in conflict: Interviews from the Bridge Network archive. Conflict Research Programme, London School of Economics and Political Science, London, UK.

Retrieved from http://eprints.Ise.ac.uk/110969/ 
Brophy, M. (2020). The role of NGOs in supporting education in Africa. Journal of International and Comparative Education (JICE), 45-56. Retrieved from

http://jml.um.edu.my/index.php/JICE/article/view/23553

Buchanan, E., et al. (2019). Teachers for change: Supporting teachers for gender-transformative education in South Sudan (Oxfam Advocacy Brief). Oxfam International. Retrieved from https://teachertaskforce.org/sites/default/files/2021-

03/Supporting\%20Teachers\%20for\%20Gender\%20Transformative\%20Education\%20in\%20Sout h\%20Sudan\%20\%28002\%29.pdf

Bul, B. E. (2019). Difficulties faced by South Sudan and international education partners in encouraging female education. International Journal of Academic Research and Reflection, 7(4), 52-60. Retrieved from http://www.idpublications.org/wp-content/uploads/2019/08/FullPaper-DIFFICULTIES-FACED-BY-SOUTH-SUDAN-AND-INTERNATIONAL-EDUCATIONPARTNERS-IN-ENCOURAGING-FEMALE-EDUCATION.pdf

Cambridge Education. (2020). GESS exceeds ambitious targets to support South Sudanese girls to stay in school. Cambridge Education. Retrieved from https://www.camb-

ed.com/intdev/article/553/gess-exceeds-ambitious-targets-to-support-south-sudanese-girls-tostay-in-school

Checchi, F., Testa, A., Warsame, A., Quach, L., \& Burns, R. (2018). Estimates of crisisattributable mortality in South Sudan, December 2013-April 2018: A statistical analysis. London School of Hygiene and Tropical Medicine. Retrieved from https://www.Ishtm.ac.uk/south-sudanfull-report

Clugston, N. (2018). Breaking barriers to girls' education by breaking cycles of poverty - cash transfers in South Sudan: A case study. Girls' Education South Sudan/Charlie Goldsmith Associates. Retrieved from https://www.calpnetwork.org/wpcontent/uploads/2020/03/genderandctpgessandcga-1.pdf

Crawfurd, L. (2017, 30 October). The effect of financial aid from UK Aid Girls' Education South Sudan programme and EU IMPACT programme to education in South Sudan in 2017. Girls' Education South Sudan (GESS) and Ministry of General Education and Instruction, Republic of South Sudan. Retrieved from https://girlseducationsouthsudan.org/wpcontent/uploads/2020/06/The-effect-of-GESS-and-IMPACT-financial-aid-to-education-in-SouthSudan-in-2017-vf.pdf

Daoust, G. (2018). Education and the critique of liberal peacebuilding: The case of South Sudan. Doctoral dissertation, University of Sussex, UK. Retrieved from http://sro.sussex.ac.uk/id/eprint/76635/

de Garang, A. (2019, 25 September). Challenges for women's and girls' in [sic.] education in South Sudan and the way forward. [Girls' Education South Sudan (GESS) blog post]. Retrieved from https://girlseducationsouthsudan.org/challenges-for-womens-and-girls-in-education-insouth-sudan-and-the-way-forward/

de Waal, A., Ibreck, R., Pendle, N., Logan, H., \& Robinson, A. M. (2017, October). South Sudan synthesis paper. Conflict Research Programme, London School of Economics and Political Science, UK. Retrieved from http://eprints.Ise.ac.uk/100159/4/De_Waal_south_sudan_synthesis_paper_published.pdf 
Diaz-Varela, A., MacEwen, L., \& Vaessen, J. (2016). What to prioritize when everything is a priority? Crisis-sensitive education sector planning in South Sudan. Paris: International Institute for Educational Planning (IIEP). Retrieved from http://education4resilience.iiep.unesco.org/sites/default/files/case-studies/246090e.pdf

Diing, A., et al. (2021). South Sudan: Youth, violence and livelihoods. Rift Valley Institute. Retrieved from https://riftvalley.net/sites/default/files/publication-

documents/RVI\%202021.06.15\%20South\%20Sudan\%20Youth\%20Violence\%20Livelihoods_Re port.pdf

Duany, J., Lorins, R., \& Thomas, E. (2021). Education, conflict and civicness in South Sudan: An introduction. South Sudan Studies Association, London School of Economics and Political Science, UK. Retrieved from http://eprints.Ise.ac.uk/108621/1/Thomas_education_conflict_and_civicness_published.pdf

Epstein, A. I. (2012). Maps of desire: Refugee children, schooling, and contemporary Dinka pastoralism in South Sudan. Doctoral dissertation, University of Wisconsin-Madison. Retrieved from

https://depot.library.wisc.edu/repository/fedora/1711.dl:J4XVUSDSX6AAS8A/datastreams/REF/c ontent

GESS (2018a). School sample survey: Endline (GESS Research Brief No. 16). Girls' Education South Sudan. Retrieved from https://girlseducationsouthsudan.org/wpcontent/uploads/2020/05/School-Sample-Survey-Endline-16.pdf

GESS (2018b). Household survey: Endline (GESS Research Brief No. 14). Retrieved from https://girlseducationsouthsudan.org/wp-content/uploads/2020/05/Household-Endline-14.pdf

GESS (2018c). Girls' Education in South Sudan (GESS) Output 1: Social \& behavioural change communication (Endline Report). Retrieved from https://girlseducationsouthsudan.org/wpcontent/uploads/2020/05/Endline-Output-1.pdf

GESS (2020a). Lessons from Girls' Education South Sudan (GESS): How to design \& implement a community mobilisation programme in a fragile and conflict affected state. Retrieved from https://girlseducationsouthsudan.org/wp-content/uploads/2020/05/How-To-CM-FINAL-1.pdf

GESS (2020b). Lessons from Girls' Education South Sudan (GESS): How to design \& implement a teacher professional development programme in a fragile and conflict affected state. Retrieved from https://girlseducationsouthsudan.org/wp-content/uploads/2020/05/How-To-TPD-FINAL1.pdf

GESS (2020c). Lessons from Girls' Education South Sudan (GESS): How to design \& implement a mentoring programme in a fragile and conflict affected state. Retrieved from https://girlseducationsouthsudan.org/wp-content/uploads/2020/05/How-To-Mentoring-FINAL1.pdf

GESS (2020d). Lessons from Girls' Education South Sudan (GESS): How to design \& implement radio programmes for social \& behavioural change in a fragile and conflict affected state.

Retrieved from https://girlseducationsouthsudan.org/wp-content/uploads/2020/05/How-ToRADIO-FINAL-1.pdf 
Ginsburg, M., Haugen, V., Lokong, F., \& Ong'uti, S. (2017). Promoting community participation in improving education in South Sudan. African Educational Research Journal, 5(4), 221-239.

Retrieved from https://files.eric.ed.gov/fulltext/EJ1214165.pdf

Haider, H. (2014). Conflict sensitivity in education, the private sector and infrastructure development (GSDRC Helpdesk Research Report No. 1136). Birmingham, UK: GSDRC, University of Birmingham. Retrieved from http://gsdrc.org/docs/open/hdq1136.pdf

Heltne, U. M., Dybdahl, R., Elkhalifa, S., \& Breidlid, A. (2020). Psychosocial support and emergency education: An explorative study of perceptions among adult stakeholders in Sudan and South Sudan. Sustainability, 12(4), 1410. Retrieved from https://www.mdpi.com/2071$1050 / 12 / 4 / 1410$

Hodgkin, E., \& Thomas, E. (2016, 6 December). Education and conflict in South Sudan [Humanitarian Practice Network blog]. Retrieved from https://odihpn.org/blog/education-andconflict-in-south-sudan/

Ibreck, R., Pendle, N., \& Robinson, A. (2021). Bridging divisions in a war-torn state: Reflections on education and civicness in South Sudan. South Sudan Studies Association, London School of Economics and Political Science, UK. Retrieved from http://eprints.Ise.ac.uk/108882/1/lbreck_bridging_divisions_in_a_war_published.pdf

Jo, S. (2019, 28 November). Female education in South Sudan: Through media and cash transfer (Peace Learner blog post). CONF 340. Retrieved from https://peacelearner.org/2019/11/28/girlseducation-in-south-sudan-through-media-and-cash-transfer/

Johnson, D. H. (2014). The political crisis in South Sudan. African Studies Review, 57(3), 167174. Retrieved from https://www.cambridge.org/core/journals/african-studiesreview/article/abs/political-crisis-in-south-sudan/C7E0D7E58615C14BC47068DC3D09EA66

Kang, T. K. (2017). Neoliberal threats to local governance in South Sudan. SSRN. Retrieved from https://papers.ssrn.com/sol3/papers.cfm?abstract_id=3147426

Kuol, L. B. D., \& Oringa, C. (2021). Is education a pathway to fostering civicness and a resilient social contract in Africa? The case of South Sudan. South Sudan Studies Association, London School of Economics and Political Science, UK. Retrieved from http://eprints.Ise.ac.uk/108620/1/Kuol_is_education_a_pathway_to_fostering_civicness_publishe d.pdf

Lodou, L. M. L., \& Oladele, O. M. (2018). Examining the status of the universal primary educational in rural area (South Sudan) . US-China Education Review, 8(7), 321-328. Retrieved from https://www.researchgate.net/profile/Lodongi-

Lodou/publication/329061418_Examining_the_Status_of_the_Universal_Primary_Educational_in _Rural_Area_South_Sudan/links/5c112850a6fdcc494feecc4f/Examining-the-Status-of-theUniversal-Primary-Educational-in-Rural-Area-South-Sudan.pdf

Mann, L. (2014). Wasta! The long-term implications of education expansion and economic liberalisation on politics in Sudan. Review of African Political Economy, 41(142), 561-578. Retrieved from https://doi.org/10.1080/03056244.2014.952276

Maphalala, T. (2015, 13 October). South Sudan celebrates its first comprehensive curriculum. The Global Partnership for Education. Retrieved from 
https://www.globalpartnership.org/blog/south-sudan-celebrates-its-first-comprehensivecurriculum

Mayai, A. T. (2021, 26 January). The economic impacts of COVID-19 pandemic in South Sudan: An update (Policy Brief). Juba: The Sudd Institute. Retrieved from https://www.jstor.org/stable/resrep29142

Mayai, A. T., \& Hammond, H. (2014). The impacts of violence on education in South Sudan. Save the Children. Retrieved from https://resourcecentre.savethechildren.net/node/19349/pdf/572b7eb3dc51e_theimpactsofviolenc eoneducationinsouth_full.pdf

McCrone, F., \& the Bridge Network. (2021). The war(s) in South Sudan: Local dimensions of conflict, governance and the political marketplace. Conflict Research Programme, London School of Economics and Political Science, UK. Retrieved from http://eprints.Ise.ac.uk/108888/1/McCrone_the_wars_in_South_Sudan_published.pdf

Millican, L. (2021). Education and stability learning journey: Lessons learned and emerging issues (K4D Emerging Issues Report No. 37). Brighton, UK: Institute of Development Studies.

MoGEI. (2016). The handbook on school governing bodies: A guide for members of parent teacher associations, school management committees, and boards of governors. Juba: Republic of South Sudan Ministry of General Education and Instruction and USAID/Room to Learn South Sudan.

Momo, E. Y. (2021). The language policy in South Sudan: Implications for educational development. South Sudan Studies Association, London School of Economics and Political Science, UK. Retrieved from http://eprints.Ise.ac.uk/108614/1/Momo_the_language_policy_in_south_sudan_published.pdf

Nicholson, S. (2018). Evaluation of Oxfam's Accelerated Education Programme in Greater Ganyliel, South Sudan 2014-2018 against global best practice. Oxfam. Retrieved from https://oxfamibis.dk/sites/default/files/media/pdf_global/evaluation_report_oxfam_alp_ganyliel_so uth_sudan_2018.pdf

Novelli, M.; Lopes Cardozo, M., \& Smith, A. (2019). The '4 Rs' as a tool for critical policy analysis of the education sector in conflict affected states. Education and Conflict Review, 2, 70-75. Retrieved from https://discovery.ucl.ac.uk/id/eprint/10081589/

Novelli, M., Daoust, G., Selby, J., Valiente, O., Scandurra, R., Kuol, L. B. D., \& Salter, E. (2016). Exploring the linkages between education sector governance, inequity, conflict, and peacebuilding in South Sudan. UNICEF Eastern and Southern Africa Regional Office (ESARO). Retrieved from https://www.researchgate.net/publication/304704723_Exploring_the_Linkages_between_Educati on_Sector_Governance_Inequity_Conflict_and_Peacebuilding_in_South_Sudan/related

O'Grady, N. (2017). Realising potential: Evaluation of Norway's support to education in conflict and crisis through civil society organisations. South Sudan: Desk Study Report. Norad. Retrieved from https://www.norad.no/en/toolspublications/publications/2017/realising-potential-evaluationof-norways-support-to-education-in-conflict-and-crisis-through-civil-society-organisations/

Oringa, C. \& Koul Deng, L. B. (2021) Is education a pathway to fostering civicness and a resilient social contract in Africa? The case of South Sudan. Education, Conflict and Civicness in South 
Sudan. London: Conflict Research Programme, London School of Economics and Political Science, UK. Retrieved from http://eprints.Ise.ac.uk/108620/

Pendle, N. R. (2020). The 'Nuer of Dinka money' and the demands of the dead: Contesting the moral limits of monetised politics in South Sudan. Conflict, Security \& Development, 20(5), 587605. Retrieved from https://doi.org/10.1080/14678802.2020.1820161

Pendle, N. R. (2021). Commanders, classrooms, cows and churches. In W. Adebanwi \& R. Orock (eds.). Elites and the politics of accountability in Africa (Chapter 12). Ann Arbor, Ml: University of Michigan Press.

Philip, P., Hartley, J., Benington, J., \& Simmons, M. (2019, 9-12 September). Inclusion and diversity to support girls' education in a context of low literacy: Innovative projects in South Sudan. Paper presented at Pan-Commonwealth Forum, Edinburgh, Scotland. Retrieved from http://oasis.col.org/handle/11599/3317

Price, R. A. (2019). Lessons learned from education programmes' contribution to peace and stability (K4D Helpdesk Report No. 577). Brighton, UK: Institute of Development Studies. Retrieved from https://opendocs.ids.ac.uk/opendocs/handle/20.500.12413/14482

Pritchard, M. \& Verjee, A. (2021). South Sudan: From 10 states to 32 states and back again. Washington, DC: United States Institute of Peace

Raza, W. A., Kabir, M. M., \& Rashid, R. (2019). Factors affecting early grade educational attainment: Evidence from South Sudan. International Journal of Educational Development, 65, 92-97.

Reisman, L., \& Janke, C. (2015). Conflict-sensitive teacher education: Viewing EDC's experience with the South Sudan teacher education project through a conflict-sensitive lens. Journal on Education in Emergencies, 1(1), 131-166. Retrieved from http://idd.edc.org/sites/idd.edc.org/files/Conflict\%20Sensitive\%20Teacher\%20Education\%20Fina I.pdf

Skårås, M. (2019). Constructing a national narrative in civil war: History teaching and national unity in South Sudan. Comparative Education, 55(4), 517-535.

Skårås, M., Carsillo, T., \& Breidlid, A. (2020). The ethnic/local, the national and the global: Global citizenship education in South Sudan. British Journal of Educational Studies, 68(2), 219-239.

Retrieved from https://doi.org/10.1080/00071005.2019.1598540

Sparks, J. (2021, 1 June). This impoverished school shows how cuts to UK's foreign aid budget hurt those most in need. Sky News. Retrieved from https://news.sky.com/story/thisimpoverished-school-shows-how-cuts-to-uks-foreign-aid-budget-hurt-those-most-in-need12321522

Târlea, S., Han, C., Nugroho, D., \& Karamperidou, D. (2021). Time to teach - Teacher attendance and time on task in primary schools in South Sudan. Florence: UNICEF Office of Research - Innocenti. Retrieved from https://www.unicefirc.org/publications/pdf/TTT\%20SOUTH\%20SUDAN.pdf

Thomas, E. (2015). South Sudan: A slow liberation. London: Zed Books. 
Toma, I. (2019). Education-focused gender analysis case studies: Pibor and Juba, South Sudan. Oxfam. Retrieved from https://oxfamilibrary.openrepository.com/handle/10546/620722

UNESCO. (2020, 16 October). Teachers trained on distance teaching through radio in South Sudan. Retrieved from https://en.unesco.org/news/teachers-trained-distance-teaching-throughradio-south-sudan

UNICEF. (2020). Education in South Sudan (Briefing Note). Retrieved from https://www.unicef.org/southsudan/media/5101/file/Education_Briefing_Note_June_Final.pdf

Vanner, C., Levi, T. K., \& Akseer, S. (2019). South Sudanese primary school textbooks:

Transforming and reinforcing conflict. Prospects, 48, 193-213. Retrieved from https://link.springer.com/article/10.1007\%2Fs11125-019-09452-2

Vinogradova, E. (2014). South Sudan Teacher Education Program (SSTEP) early grade reading assessment report. USAID. Retrieved from https://pdf.usaid.gov/pdf_docs/PA00M4R1.pdf

Wawa, Y. (2021). Civicness in South Sudan secondary school curriculum. South Sudan Studies Association, London School of Economics and Political Science, UK. Retrieved from http://eprints.Ise.ac.uk/108865/1/Wawa_civicness_in_curriculum_south_sudan_published.pdf

Winrock International. (2017). Lessons learned in addressing access to education in South Sudan through community engagement, school governance, conflict sensitivity, and teacher development (Room to Learn Technical Reflection Paper). Retrieved from https://winrock.org/wpcontent/uploads/2017/03/RtL_Technical-Reflection-Paper-vF.pdf

Xinhua. (2021, 3 May). School reopens in South Sudan after more than a year of closure. CGTN. Retrieved from https://africa.cgtn.com/2021/05/03/school-reopens-in-south-sudan-after-morethan-a-year-of-closure/ 